\title{
Differentiating morpho-functional patterns of the five most common deep-sea benthic anglerfishes (Lophiiformes) from Andaman and Nicobar Islands (eastern Indian Ocean)
}

\author{
Meleppura Rajeeshkumar ${ }^{1}$, Kannamkulathil Vijayan Aneesh Kumar ${ }^{1}$, José Luís Otero-Ferrer ${ }^{2}$, \\ Antoni Lombarte ${ }^{3}$, Manjebrayakath Hashim ${ }^{1}$, Narayanane Saravanane ${ }^{1}$, Veloorkirakathil \\ Narayanan Sanjeevan ${ }^{4}$, Mallavarapu Venkata Ramana Murthy ${ }^{1}$, Víctor Manuel Tuset ${ }^{3}$ \\ ${ }^{1}$ Centre for Marine Living Resources and Ecology, Ministry of Earth Sciences, Govt. of India, Kakkanad, Cochin 682037, \\ India. \\ (MR) E-mail: rajeeshmeleppura@gmail.com. ORCID iD https://orcid.org/0000-0002-1223-2904 \\ (KVAK) (Corresponding author) E-mail: aneeshmenan12@gmail.com. ORCID iD: https://orcid.org/0000-0002-0551-3505 \\ (MH) E-mail: hashimaqua@gmail.com. ORCID iD: https://orcid.org/0000-0001-6556-7364 \\ (NS) E-mail: saravanane@cmlre.gov.in. ORCID iD: https://orcid.org/0000-0003-3405-4923 \\ (MVRM) E-mail: mvramana.m@cmlre.gov.in. ORCID iD: https://orcid.org/0000-0001-6429-1511 \\ ${ }^{2}$ Biostatech, Advice, Training and Innovation in Biostatistics (Ltd), Edificio Emprendia, Campus Vida s/n, 15782 Santiago \\ de Compostela, Spain. \\ (JLO) E-mail: joseluis.oteroferrer@gmail.com. ORCID iD: https://orcid.org/0000-0003-1078-4008 \\ ${ }^{3}$ Institut de Ciències del Mar (CSIC), Passeig Marítim de la Barceloneta 37-49, 08003 Barcelona, Catalonia, Spain. \\ (AL) E-mail: toni@icm.csic.es. ORCID iD: https://orcid.org/0000-0001-5215-4587 \\ (VMT) E-mail: vtuset@icm.csic.es. ORCID iD: https://orcid.org/0000-0001-9032-2844 \\ ${ }^{4}$ Kerala University of Fisheries and Ocean Studies (KUFOS), Panangad, Cochin 682506 India. \\ (VNS) E-mail: sanjeevanmoes@ gmail.com. ORCID iD: https://orcid.org/0000-0002-8380-9934
}

\begin{abstract}
Summary: Anglerfishes are widely distributed from shallow to deep-water habitats occupying different ecological niches. To explain this adaptability, we performed a morpho-functional study on common benthic anglerfishes inhabiting the Indian deep-sea waters. Sensory capabilities of species were examined using the morphology and morphometry of sagitta otoliths (related to detection sound and hearing) and eye size (related to visual communication). We also performed an analysis of the degree of functional niche overlap using fish body traits to understand the coexistence of species. Otoliths showed a morphological pattern similar to that of other anglerfishes: an archaesulcoid sulcus acusticus and variability in the irregularity of the dorsal margin. This last feature affected the allometric relationships between the otolith morphometry and fish length, as well as the otolith relative sizes of each species. The findings suggested that bigger otoliths are associated with the increase of depth distribution of species up to $1000 \mathrm{~m}$, from which it decreases. Our hypothesis is that anglerfishes with irregular otolith shapes could be linked to more nocturnal feeding behaviour because they were characterized by greater eye sizes. The results also indicated interspecific significant differences in functional traits providing a low niche overlap. Therefore, our study supports the hypothesis of an environmental and ecological specialization of benthic anglerfishes.
\end{abstract}

Keywords: fish body traits; otolith shape; ecomorphology; Lophiiformes.

Diferenciando las características morfo-funcionales de las cinco especies más comunes de rapes de aguas profundas (Lophiiformes) de las islas de Andaman y Nicobar (Océano Índico oriental)

Resumen: Las especies del orden Lophiiformes habitan desde las aguas superficiales hasta las más profundas de los océanos ocupando diferentes nichos ecológicos. Con el fin de explicar esta adaptabilidad se llevó a cabo un estudio mofo-funcional de especies bentónicas comunes en aguas profundas del Océano Índico. La capacidad sensorial de las especies se analizó a partir de la morfología y morfometría del otolito sagitta (relacionado con la detección del sonido y la capacidad auditiva) y del tamaño del ojo (relacionado con la comunicación visual). Con el fin de comprender mejor la coexistencia entre especies, también se analizó el grado de solapamiento del nicho funcional usando atributos morfométricos del pez. Los otolitos presentaron una forma morfológica similar a otros lofiiformes: sulcus acusticus de tipo archaesulcoide y variabilidad en la irregularidad del margen dorsal. Este último carácter afectó a las relaciones alométricas entre la morfometría del otolito y la talla del pez, así como los tamañoa relativos del otolito de cada especie. Los resultados obtenidos sugieren que los otolitos más grandes estarían asociados con el incremento de la profundidad de distribución de las especies hasta los 1000 m, a partir de la cual disminuirían. La hipótesis que sustentamos es que las especies con otolitos más irregulares podrían tener un comportamiento nocturno asociado con la alimentación, ya que éstas tienen los ojos más grandes. Los resultados también indicaron diferencias interespecíficas significativas en los atributos funcionales de las especies, lo cual proporcionó un bajo solapamiento entre los nichos. En definitiva, el presente estudio apoya la hipótesis de una especialización ambiental y ecológica de las especies bentónicas de lofiiformes. 
Palabras clave: atributos del pez; forma del otolito; ecomorfología; Lophiiformes.

Citation/Como citar este artículo: Rajeeshkumar M., Aneesh Kumar K.V., Otero-Ferrer J.L., Lombarte A., Hashim M., Saravanane N., Sanjeevan V.N., Ramana Murthy M.V., Tuset V.M. 2020. Differentiating morpho-functional patterns of the five most common deep-sea benthic anglerfishes (Lophiiformes) from Andaman and Nicobar Islands (eastern Indian Ocean). Sci. Mar. 84(4): 369-384. https://doi.org/10.3989/scimar.05081.20A

Editor: G. Pequeño.

Received: May 12, 2020. Accepted: September 4, 2020. Published: October 6, 2020.

Copyright: (c) 2020 CSIC. This is an open-access article distributed under the terms of the Creative Commons Attribution 4.0 International (CC BY 4.0) License.

\section{INTRODUCTION}

The order Lophiiformes, commonly known as anglerfishes, is a diverse group of benthic and pelagic species inhabiting shallow to deep-sea waters. This order comprises approximately 358 extant species in five suborders (Pietsch and Grobecker 1987, Nelson et al. 2006): Lophioidei, Antennarioidei, Chaunacoidei, Ogcocephaloidei and Ceratioidei. Phylogenetic studies reveal that Lophioidei, the most primitive group, evolved independently of the remaining groups (Caruso 1985, Pietsch and Grobecker 1987, Pietsch and Orr 2007, Miya et al. 2010). Although some lophiiform morphological features are similar (Caruso 1983, Pietsch and Orr 2007), body shape differs between clades: dorso-ventrally flattened in Lophioidei (with rhomboidal head) and Ogcocephaloidei (with triangular or circular head) (Caruso 1985, Ho and Shao 2008), laterally compressed in Antennarioidei (Pietsch and Grobecker 1987, Arnold and Pietsch 2012) and globose in Chaunacoidei (Ho and Ma 2016). In Ceratioidei, species are characterized by specific morphologies adapted to mesopelagic and bathypelagic lifestyle, which has led to their rapid diversification (Miya et al. 2010). In general, lophiiforms are opportunistic (non-selective) ambushers, luring their prey by raising and moving the illicium, a modified first dorsal-fin spine with a terminal esca (bait) (Pietsch and Grobecker 1987, Afonso-Dias 1997). The Ogcocephaloidei species seem to be more adapted for the capture of small demersal prey (durophagy) such as gastropods, small crustaceans and polychaetes (Gibran and Castro 1999, Nagareda and Shenker 2008). Indistinctly, all species are considered top-predators where the capture efficiency is favoured by a jet-propulsive locomotion, which is produced through pore-like gill openings behind the pectoral fin (Pietsch 1981).

The Indian Ocean, and especially the region around the Andaman and Nicobar Islands, is characterized by their rich deep-sea fishery resources (Venu and Kurup 2002, Jayaprakash et al. 2006, Hashim 2012, Sumod 2018, Rajeeshkumar 2018). Recent experimental surveys have reported 22 lophiiforms (Rajeeshkumar 2018). This eco-evolutionary scenario necessarily implies a high interspecific phenotypic variability leading to coexistence or segregation of species. It is known that this phenotypic variability is linked to multiple extrinsic
(Colborne et al. 2013, Aguilar-Medrano et al. 2016) and genetic factors (Pietsch and Orr 2007, Miya et al. 2010, Arnold 2015), avoiding direct competition for feeding resources (Bellwood et al. 2010, Frederich et al. 2016). For example, the distribution range or temporal segregation in the behavioural activity could play a key role in the coexistence for many sympatric species (Carothers and Jaksić 1984, Seehausen et al. 2008, Foster et al. 2015), as occurs between Lophius budegassa and L. piscatorius on the continental shelf and upper slope of the Mediterranean Sea. Both species have similar prey preferences (Preciado et al. 2006, Bohórquez-Herrera 2015), but they have developed sensory specialization in eye and otolithic organs that allows L. budegassa to be more active at night, whereas L. piscatorius is more active during daytime (Hislop et al. 2000, Colmenero et al. 2010). Thus, sensory (visual and hearing) and morpho-functional features of an organism can be used to discern and understand the ecological segregation among species (Lombarte 1992, Arellano et al. 1995, Tuset et al. 2016). Overall ecomorphological studies on the ecology of lophiiforms are scarce (Carlucci et al. 2009, Colmenero et al. 2010), and there are none for the species inhabiting the Indian Ocean.

The aim of this work is to understand better the coexistence of the most common benthic species of lophiiforms occurring at the Andaman and Nicobar Islands (Rajan and Sreeraj 2013, Balakrishnan et al. 2008, Hashim 2012, Rajeeshkumar et al. 2016, 2017 , Ho et al. 2016a): Chaunax apus Lloyd, 1909 and $C$. multilepis Ho, Rajeesh and Bineesh, 2016 (Chaunacidae), Halieutaea coccinea Alcock, 1894 and Malthopsis lutea Alcock 1891 (Ogcocephalidae), and Lophiodes lugubris (Alcock, 1894) (Lophiidae). To this end, we characterized the sagitta otolith (henceforth otolith) morphology for each species that may be essential for building marine food webs (Lombarte et al. 2010, Tuset et al. 2008, 2010, 2018), analysed the morphometric relationships of otoliths with fish length as an indirect factor of the range of spatial distribution in depth of the species (Tuset et al. 2010, Colmenero et al. 2010, Nazir and Khan 2019) and obtained functional traits as an indicator of ecological strategies and to detect the degree of functional niche overlapping between species (Gatz 1979, Sibbing and Nagelkerke 2001, Karpouzi and Stergiou 2003, Wainwright et al. 2007). 


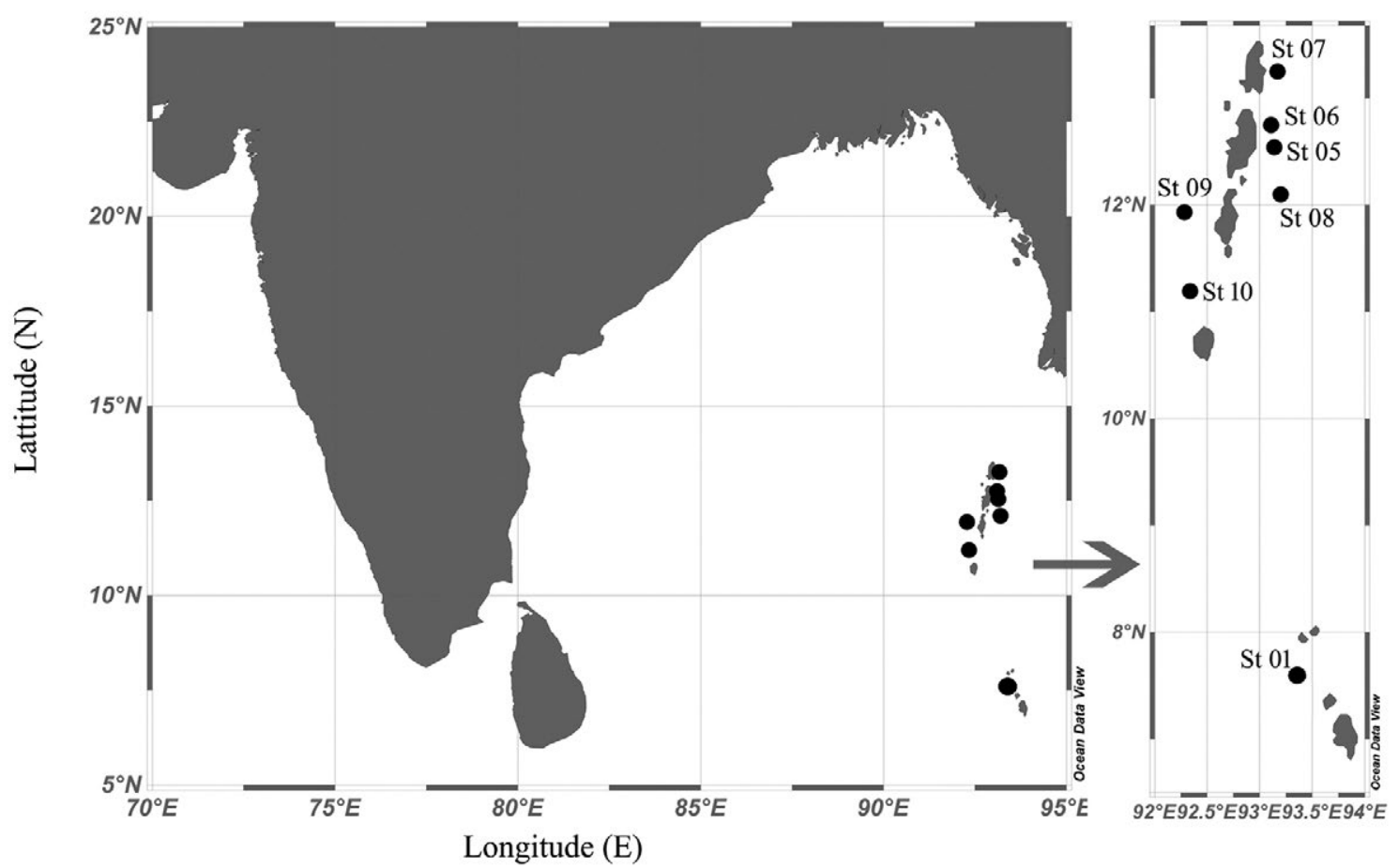

Fig. 1. - Geographical locations of the five most common deep-sea benthic anglerfishes sampled from the Andaman and Nicobar Islands (eastern Indian Ocean).

\section{MATERIALS AND METHODS}

\section{Data collection}

Specimens were collected during the deep-sea fishery exploratory surveys of the Fishery Oceanographic Research Vessel (FORV) Sagar Sampada (71.5 m L $\mathrm{OA}_{\text {: }}$ : 2285 hp) (Cruise no 349) in Andaman and Nicobar waters in April 2016 using a High-Speed Demersal Trawl -crustacean version (HSDT-CV) at a towing speed of 2.5 to 3.5 knots. Eight stations were surveyed (one operation at each station) along the continental margins of the Andaman and Nicobar Islands $\left(7.29-13.76^{\circ} \mathrm{N}\right.$ and $92.14-93.11^{\circ} \mathrm{E}$ ) at depths ranging from 300 to 650 m (Fig. 1). The locations were scanned using a SIMRAD EK60 echo sounder before trawling operations and stations were selected on the basis of the suitability of the grounds for trawling. The fishing operations were carried out from 6 am to $6 \mathrm{pm}$ depending upon the weather conditions.

The lophiiforms were identified following standard identification keys (Alcock 1891, 1894, Rajeeshkumar et al. 2016, Ho et al. 2016a, b). Only non-damaged adult fishes were selected for meristic and morphological measurements and to extract the otoliths. The catch per unit effort (CPUE) and the spatial distribution of each species along with their geographical positions are given in the Figure 2.

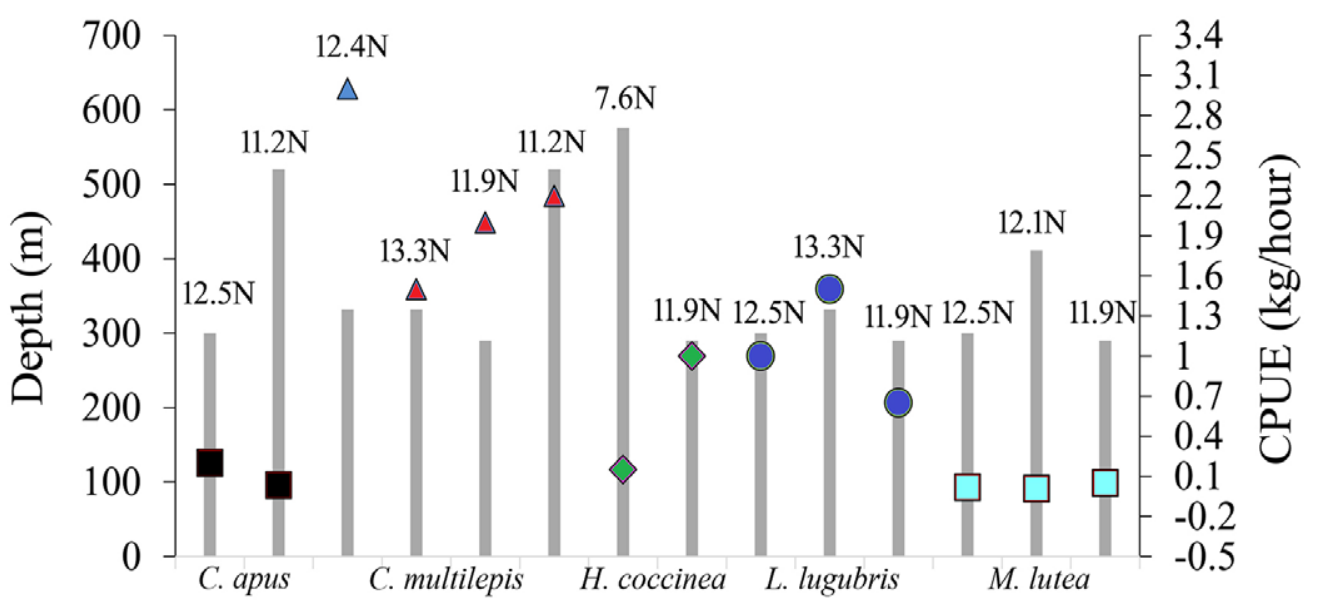

Fig. 2. - Catch per unit effort (CPUE) of the five most common deep-sea benthic anglerfishes at various stations (y-axis) of the Andaman and Nicobar Islands (eastern Indian Ocean). Station depth is indicated below the respective stations (x-axis). (N, north, indicating the geographical location). 


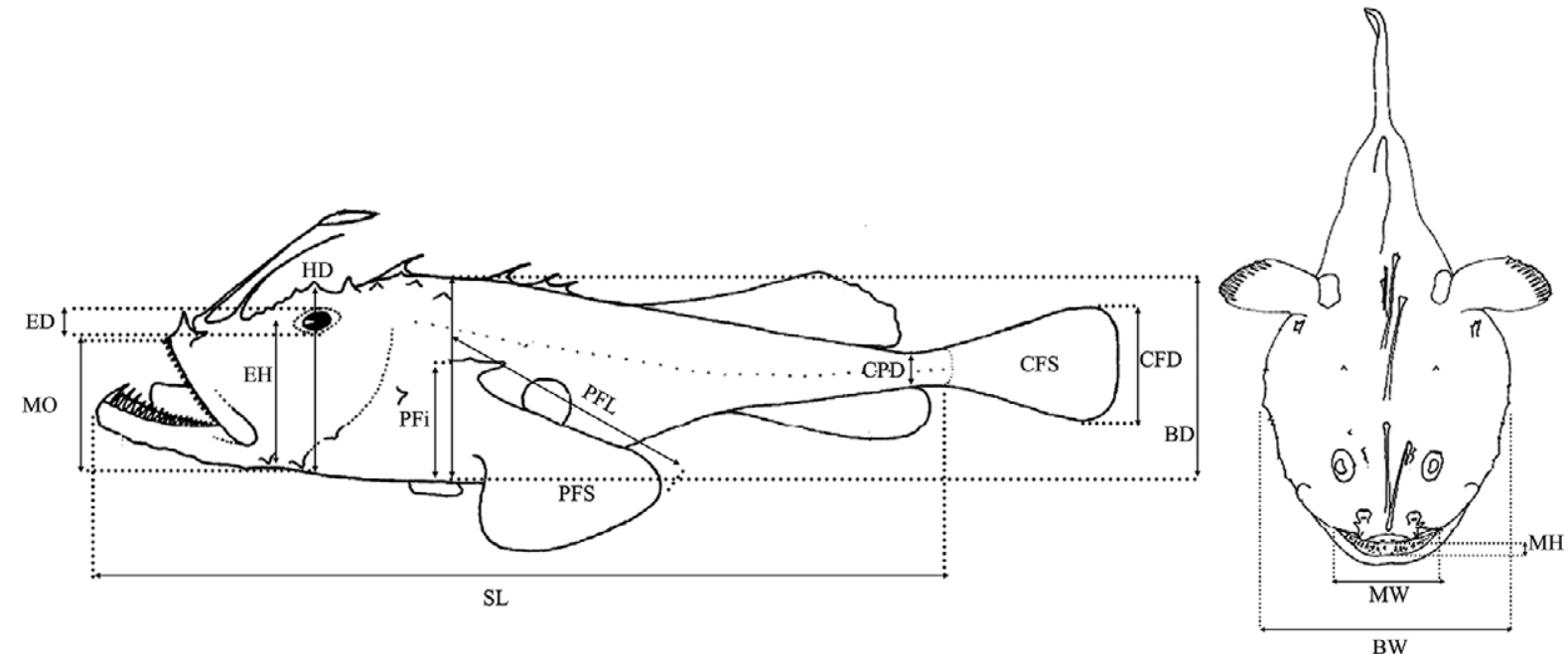

Fig. 3. - Illustration of the morphological traits of the fishes measured for estimating functional indices (after Albouy et al. 2011). $B D$, body depth; $B W$, body width; $C F D$, caudal fin depth; $C P D$, caudal peduncle minimal depth; $E D$, eye diameter; $E H$, distance between the bottom of the head and the eye centre along the head depth axis; $H D$, head depth along the vertical axis of the eye; $M H$, mouth height; $M O$, mouth opening; $M W$, mouth width; $P F B$, body depth at the level of the pectoral fin insertion; $P F i$, distance between the insertion of pectoral fin and the bottom of the body; PFL, pectoral fin length; PFS, pectoral fin surface; SL, standard length. Fish drawings after Caruso (1981, 2002).

\section{Otolith morphology and morphometry}

Otoliths were collected and washed with distilled water to remove exogenous matter, dried and kept in plastic vials for further analysis. Otoliths from the right side of each fish were oriented with the inner side (sulcus acusticus) uppermost on a slide in order to digitize their form using a microscope (S8APO Camera, Leica DFP-425). Otolith length $(O L, \mathrm{~mm})$, height $(\mathrm{OH}, \mathrm{mm})$, area $\left(O A, \mathrm{~mm}^{2}\right)$ and perimeter $(O P, \mathrm{~mm})$ were measured using ImageJ with magnification depending on otolith size. Otolith weight $(O W, \mathrm{mg})$ was obtained using an electronic balance (Metler Toledo, ML 503) (see descriptive values in Appendix 1). The morphological characteristics of each species were described following Tuset et al. (2008).

\section{Fish body morphological data}

Sixteen morphological variables were measured on each specimen using a Vernier calliper $(0.1 \mathrm{~mm}$ precision): total length (TL), standard length $(S L)$, eye diameter $(E D)$, mouth opening $(M O)$, head depth $(H D)$, eye height $(E H)$, pectoral fin base $(P F B)$, pectoral fin insertion, pectoral fin length $(P F L)$, pectoral fin surface $(P F S)$, caudal peduncle depth $(C P D)$, caudal fin surface $(C F S)$, caudal fin depth $(C F D)$, body depth $(B D)$, body length, body width $(B W)$, mouth height $(M H)$ and mouth width $(M W)$ (Fig. 3). From these measurements, the following 11 ecomorphological attributes correlated with foraging, manoeuvrability and locomotion were selected for detailed studies. The formulas for estimating the functional traits are given in italicized letters.

- Oral gape surface $(O s f)=(M W \times M H) /(B W \times B D)$, which indicates the nature/size of the prey that can be captured. A large oral gape allows feeding on a wide size range including large prey (Karpouzi and Stergiou 2003).
- Oral gape shape $(O s h)=M H / M W$, which defines the method for capturing food items. A greater width allows species to capture highly mobile prey and have a more aggressive behaviour (Karpouzi and Stergiou 2003, Wainwright et al. 2007).

- Oral gape position $(O p s)=M O / H D$, which shows the feeding position in the water column. The position of the oral gape influences the retention of prey during ingestion (Kumar et al. 2017a, Villéger et al. 2017).

- Eye size $(E d s t)=E D / H D$, which defines the prey detection efficiency. It also influences the feeding rhythms (nocturnal vs diurnal) and predator avoidance and indicates the availability of light in the microhabitat (Boyle and Horn 2006, Bellwood et al. 2014).

- Eye position $(E p s)=E H / H D$, which displays the vertical position in the water column. High values indicate dorsally located eyes (Watson and Balon 1984, Ribeiro et al. 2016).

- Body transversal shape $(B s h)=B D / B W$, which indicates the vertical position of the fish in the water column as well as hydrodynamic efficiency (Villéger et al. 2017).

- Caudal peduncle throttling $(C p t)=C F D / C P D$, which shows the caudal propulsion efficiency through the reduction of drag (Webb 1984, Zhao et al. 2014).

- Fin surface ratio $(F s r)=(2 \times P F S) / C F S$, which indicates the type of propulsion between caudal and pectoral fins. Higher values denote a swimming driven by pectoral fins, whereas lower values correspond to a greater caudal fin propulsion (Mouillot et al. 2013, Zhao et al. 2014).

- Fin surface to body size ratio $(F s b)=((2 \times P F S)+$ $C F S) /(\pi / 4 \times \mathrm{BW} \times \mathrm{BD})$, which indicates the acceleration and/or manoeuvring competence. Higher values indicate prolonged sustained swimming speed and fitness, which positively influence endurance, acceleration and manoeuvring capacities (Zhao et al. 2014, Kumar et al. 2017a). 
- Aspect ratio of the pectoral fin $(A r P F)=P F L^{2 /}$ $P F S$, an indicator of swimming ability, which helps sustained swimming. Longer pectoral fins favour sustained swimming speed (Watson and Balon 1984, Casatti and Castro 2006).

- Aspect ratio of the caudal fin $(A r C F)=C F D^{2} / C F S$, which indicates the caudal fin use for propulsion and/ or direction. A higher ratio produces the maximum thrust (Webb 1984, Bridge et al. 2016).

To estimate the functional traits, the morphological data were standardized to remove the allometric effect using the total weight (Mouillot et al. 2005, Kumar et al. 2017a). The allometric relationship between morphological data $(X)$ and body mass $(M)$ is $X=a M^{b}$, where ' $b$ ' varies with species. The effect of body mass was eliminated by using the residuals of the common within-group slopes of linear regressions for each component of body mass.

\section{Statistical analysis}

The Kolmogorov-Smirnov and Levene tests were used to check normality of the data distributions and variance homogeneity, respectively. The intraspecific variability was analysed considering the fish size-otolith measurement relationships as a tool in the feeding ecology to estimate fish size and biomass (Kumar et al. 2017b, c) and the otolith relative size as a resemblance to fish habitat and depth distribution (Lombarte and Cruz 2007). For the first analysis, the relationships between otolith morphometric variables $(O L, O H, O A$, $O P, O W)$ were described using the allometric power equation $\left(Y=a X^{\mathrm{b}}\right)$ (Huxley 1924). Measurements were converted into logarithmic values $\left(\log _{10}\right)$ to identify and exclude possible outliers in the data (Froese et al. 2011). Regression parameters $a$ and $b$ were estimated by the least square regression method, where $b$ represents the constant of differential growth rate (Froese 2006). An analysis of covariance (ANCOVA) was performed to compare the regression slopes between species, treating the species as the main factor and fish size $(S L)$ as a covariate. Specific difference was analysed using a post-hoc Tukey-HSD test. In the second analyses, the otolith measurements were standardized for each species by removing the effect of allometry (Lleonart et al. 2000). Different relative sizes were estimated for each otolith morphometric variable using the following criteria (Lombarte and Cruz 2007): $O R_{i}=$ (otolith variable) ${ }_{i} S L^{\mathrm{b}}$, with $b=1$ for $O L, O H$ and $O P$ variables, $b=2$ for $O A$ and $b=3$ for $O W$. An ANOVA was conducted for each variable on the relative size to test differences in the averages among species. A posthoc test (Dunn's test) was performed to elucidate the pairwise comparison of relative otolith sizes (Pohlert 2014). All statistical analyses were performed in PAST (PAlaeontologicalSTatistics, version 3.26) (Hammer et al. 2001).

To order species in the functional space, a principal component analysis (PCA) based on the correlation matrix of the functional traits was performed. The choice of which principal components to interpret was based on a broken-stick model, which constructs a null distribution of eigenvalues and compares it with observed ones (Collar and Wainwright 2006, Villéger et al. 2011). Our hypothesis of significant difference among the species and Bonferroni's correction for post-hoc pairwise multiple comparisons were tested using multivariate analysis of variance (MANOVA) (Marcus 1993, Layman et al. 2005, Marrama and Kriwet 2017).

The degree of functional niche overlap among species was performed using a non-parametric kernel density function $\left(N O_{K}\right)$ (Mouillot et al. 2005, Mason et al. 2008, Geange et al. 2011):

$$
N O_{K w}(i, j)=\frac{1}{\sum_{t=1}^{T} W_{t}} \sum_{t=1}^{T} w_{t} N O_{K}(i, j, t)
$$

$N O_{K}(i, j, t)$ is the niche overlap between species $i$ and $j$ for the trait $t, T$ is the number of functional traits and $w_{\mathrm{t}}$ is the weighting parameter, which is calculated as:

$$
w_{t}=\frac{1}{2}+\sum_{t=1}^{T}\left(1-\frac{r_{t l}^{2}}{2}\right)
$$

$r_{t l}$ is the Pearson correlation coefficient between traits $t$ and $l$ over all five species selected for the study. To understand the niche differences between the anglerfishes, permutation tests were performed to assess whether the observed niche overlap was significantly low based on the potential distribution of niche overlap values (Mouillot et al. 2005, Mason et al. 2008, Geange et al. 2011). Pseudo-values were calculated through randomly permuting species types in the corresponding data set for more than 1000 runs followed by computing the distribution of the average niche overlap for the null model to create the statistical null distributions. A Bonferroni adjustment of type I (Quinn and Keough 2002) was performed for the multiple comparisons. Density functions available in R ( $R$ Development Core Team 2017) were used to calculate niche overlap and for the subsequent null model tests. We followed the source code provided by Geange et al. (2011) for the above analysis in the $\mathrm{R}$ environment.

\section{RESULTS}

\section{Otolith anatomical description}

All species shared otolith features such as dorsal lobes and the lightly marked sulcus acusticus, with a well-defined crista inferior (Fig. 4). The otoliths of Chaunacidae (C. apus and C. multilepis) are characterized by a sulcus acusticus with undifferentiated ostium and cauda referred to as archaesulcoid. Indeed, they maintain an oval shape throughout growth with a smoothed and deep convex ventral margin. The dorsal margin has a variable number of lobes depending on species. In general, C. apus have more lobes (5 to 7) that are less angled than in C. multilepis. In Ogcocephalidae species, otoliths show a stronger differentiation in shape: $H$. coccinea has a semi-circular pattern (in the largest specimens), with a high number of deep lobes (6 to 10), some irregularities on the dorsal mar- 


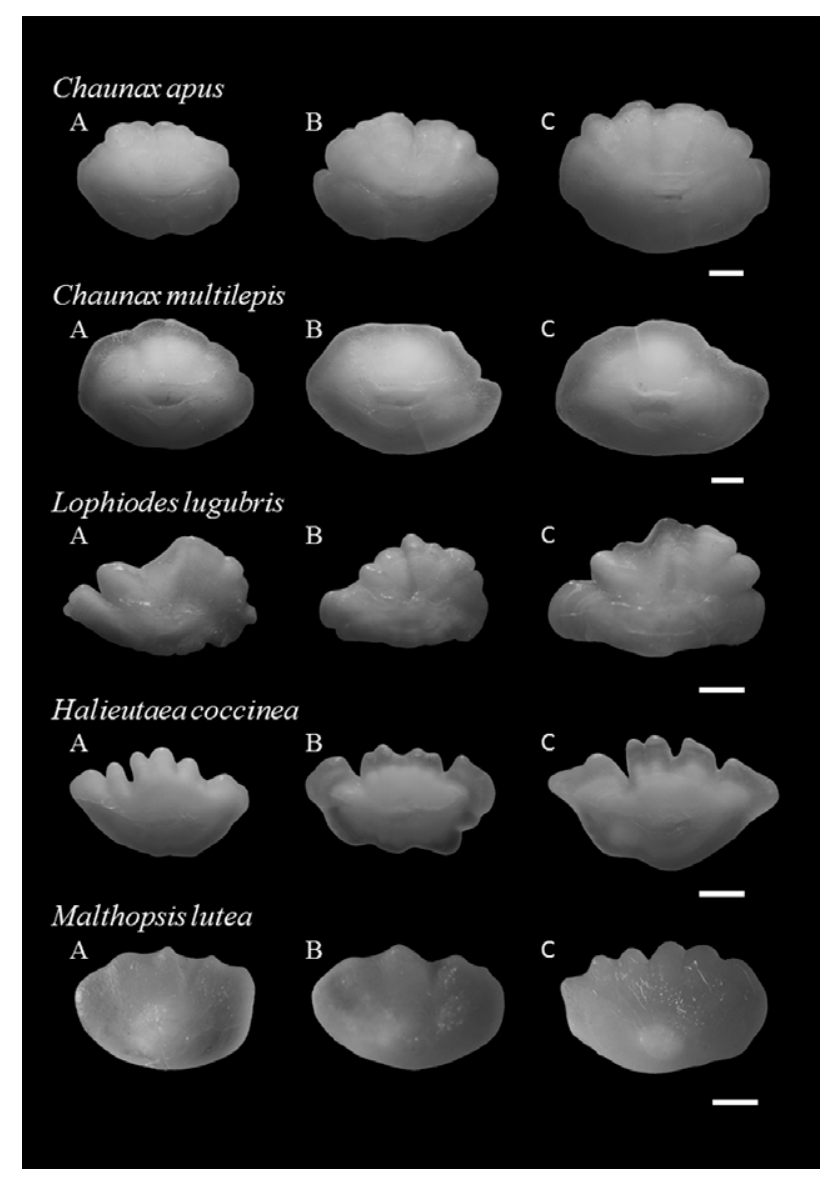

Fig. 4. - Left otoliths for the five most common deep-sea benthic anglerfishes from the Andaman and Nicobar Islands (eastern Indian Ocean). Chaunax apus: A, $T L=9.1 \mathrm{~cm} ; \mathrm{B}, T L=9.5 \mathrm{~cm} ; \mathrm{C}, T L=12.0$ cm. Chaunax multilepis: A, $T L=9.0 \mathrm{~cm} ; \mathrm{B}, T L=12.1 \mathrm{~cm} ; \mathrm{C}, T L=13.0$ $\mathrm{cm}$. Lophiodes lugubris: A, $T L=12.4 \mathrm{~cm} ; \mathrm{B}, T L=14.5 \mathrm{~cm}$; C, $T L=17.1 \mathrm{~cm}$. Halieutaea coccinea: A, $T L=8.5 \mathrm{~cm} ; \mathrm{B}, T L=11.2$ $\mathrm{cm} ; \mathrm{C}, T L=11.5 \mathrm{~cm}$. Malthopsis lutea: A, $T L=7.4 \mathrm{~cm} ; \mathrm{B}, T L=7.5 \mathrm{~cm}$; C, $T L=8.2 \mathrm{~cm}$. Scale bar $=1 \mathrm{~mm}$.

gin, a smooth, convex ventral margin, a rounded to angled anterior margin, and an angled end at the posterior margin for the largest specimens, providing an oblong shape. In contrast, $M$. lutea has an oval shape, with a sinuous to lightly lobed dorsal margin (3 to 6 lobes) and a smooth, shallow, convex ventral margin, and the anterior margin is oblique, lacking a rostrum. In both species the sulcus acusticus is archaesulcoid, mesial and ascendant, with an oval ostium (poorly defined) and a cauda smaller than the ostium. In particular, the sulcus acusticus of $M$. lutea is placed in an inframedian position. Finally, the otolith of L. lugubris (Lophiidae) is characterized by a semi-circular to oblong shape (in the largest specimens), with a sinusoidal ventral margin and a deeply lobed (6 to 9) irregular dorsal margin, a blunt anterior margin and an undefined rostrum and pointed end of the posterior margin of the largest specimens. The sulcus acusticus is a homosulcoid type, with oval ostium and cauda.

\section{Interspecific variability in the otolith morphometry}

All otolith morphometric variables showed a statistically significant relationship with fish length for all species (Table 1, Appendix 2). However, otolith length and weight were the best variables correlated with fish size ( $r^{2}$ ranges from 0.740 to 0.936 for $O L$, and between 0.708 and 0.959 for $O W$ ). The other variables showed a high intraspecific variation, and even attained very low values in the otolith height $\left(r^{2}=0.287\right)$ for M. lutea and the otolith perimeter $\left(r^{2}=0.243\right)$ for $H$. coccinea (Table $1)$. The ANCOVA exhibited no differences between species in the slopes of relationships $S L-O H(F=0.879$, $d f=4, p=0.482)$ and $S L-O A(F=2.158, p=0.085)$, but it indicated interspecific variability for the $S L-O L$ $(F=4.764, d f=4, p=0.002), S L-O P(F=2.705, d f=4$, $p=0.039)$ and $S L-O W(F=6.787, d f=4, p<0.001)$ relationships (Appendix 3). In particular, the slope $(b)$ for the $S L-O W$ relationship was higher in $M$. lutea than in C. apus-H. coccinea, and higher in L. lugubris than in $H$. coccinea. In fact, $H$. coccinea and $L$. lugubris also varied for the $S L-O P$ and $S L-O L$ relationships, and $L$. lugubris also showed differences with $C$. apus for the latter.

The ANOVA tests revealed significant differences for all relative variables $\left(O A_{R}, F=166.2, d f=4, p<0.05\right.$; $O L_{R}, F=120.1, d f=4, p<0.05 ; O H_{R}, F=309.8, d f=4$, $p<0.05 ; O P_{R}, F=46.6, d f=4, p<0.05 ; O W_{R}, F=124.1$, $d f=4, p<0.05)$. Pairwise comparison using Dunn's test (Bonferroni, $p<0.05$ ) indicated significant inter-species differences, except between Chaunax spp. (Fig. 5, Table 2). The highest interspecific variability was ob-

Table 1. - Regression parameters of the relationships between otolith measurements and fish length of the five most common deep-sea benthic anglerfishes from the Andaman and Nicobar Islands (eastern Indian Ocean). $a$, intercept; $b$, slope; n, number of specimens; $O A$, otolith area; $O H$, otolith height; $O L$, otolith length; $O P$, otolith perimeter; $O W$, otolith weight; $r^{2}$, coefficient of determination; se, standard error of $b$; $S L$, standard length. The $b$ values following with superscript letters indicates significant differences $(p<0.001)$.

\begin{tabular}{|c|c|c|c|c|c|c|c|c|c|c|c|c|c|c|c|}
\hline \multirow[b]{2}{*}{ Relationship } & \multicolumn{5}{|c|}{ Chaunax apus } & \multicolumn{5}{|c|}{ Chaunax multilepis } & \multicolumn{5}{|c|}{ Halieutaea coccinea } \\
\hline & $\mathrm{n}$ & $a$ & $b$ & se $(b)$ & $r^{2}$ & $\mathrm{n}$ & $a$ & $b$ & $\operatorname{se}(b)$ & $r^{2}$ & $\mathrm{n}$ & $a$ & $b$ & $\operatorname{se}(b)$ & $r^{2}$ \\
\hline$S L-O A$ & 10 & 0.170 & 1.06 & 0.081 & 0.955 & 16 & 0.150 & 1.05 & 0.148 & 0.785 & 16 & 0.070 & 1.07 & 0.127 & 0.835 \\
\hline $\mathrm{SL}-\mathrm{OH}$ & 10 & 0.490 & 0,48 & 0,039 & 0.951 & 16 & 0.800 & 0.36 & 0.077 & 0.606 & 16 & 0.260 & 0.52 & 0.089 & 0.711 \\
\hline$S L-O L$ & 10 & 0.572 & $0.53^{\mathrm{a}}$ & 0.049 & 0.925 & 16 & 0.341 & $0.63^{\mathrm{ac}}$ & 0.075 & 0.833 & 16 & 0.337 & $0.58^{a}$ & 0.069 & 0.838 \\
\hline$S L-O P$ & 10 & 0.220 & $0.59^{\mathrm{a}, \mathrm{b}}$ & 0.042 & 0.959 & 16 & 1.220 & $0.57^{\mathrm{a}, \mathrm{b}}$ & 0.083 & 0.768 & 16 & 3.370 & $0.33^{\mathrm{b}}$ & 0.169 & 0.240 \\
\hline \multirow[t]{3}{*}{$S L-O W$} & 10 & 0.049 & $1.50^{\mathrm{ac}}$ & 0.110 & 0.958 & 16 & 0.020 & $1.64^{\mathrm{ab}}$ & 0.281 & 0.708 & 16 & 0.047 & $1.24^{\mathrm{a}}$ & 0.109 & 0.902 \\
\hline & \multicolumn{5}{|c|}{ Lophiodes lugubris } & \multicolumn{5}{|c|}{ Malthopsis lutea } & & & & & \\
\hline & $\mathrm{n}$ & $a$ & $b$ & se $(b)$ & $r^{2}$ & $\mathrm{n}$ & $a$ & $b$ & se $(b)$ & $r^{2}$ & & & & & \\
\hline$S L-O A$ & 15 & 0.007 & 1.53 & 0.209 & 0.804 & 12 & 0.220 & 0,89 & 0.213 & 0.636 & & & & & \\
\hline$S L-O H$ & 15 & 0.238 & 0,53 & 0.098 & 0.690 & 12 & 1.220 & 0.29 & 0.147 & 0.287 & & & & & \\
\hline$S L-O L$ & 15 & 0.049 & $0.96^{\mathrm{bc}}$ & 0.121 & 0.829 & 12 & 0.300 & $0.53^{\mathrm{ac}}$ & 0.100 & 0.740 & & & & & \\
\hline$S L-O P$ & 15 & 0.270 & $0.82^{\mathrm{a}}$ & 0.111 & 0.805 & 12 & 1.680 & $0.46^{\mathrm{a}, \mathrm{b}}$ & 0.076 & 0.787 & & & & & \\
\hline$S L-O W$ & 15 & 0.001 & $2.01^{\mathrm{bc}}$ & 0.233 & 0.851 & 12 & 0.004 & $2.62^{\mathrm{b}}$ & 0.171 & 0.959 & & & & & \\
\hline
\end{tabular}



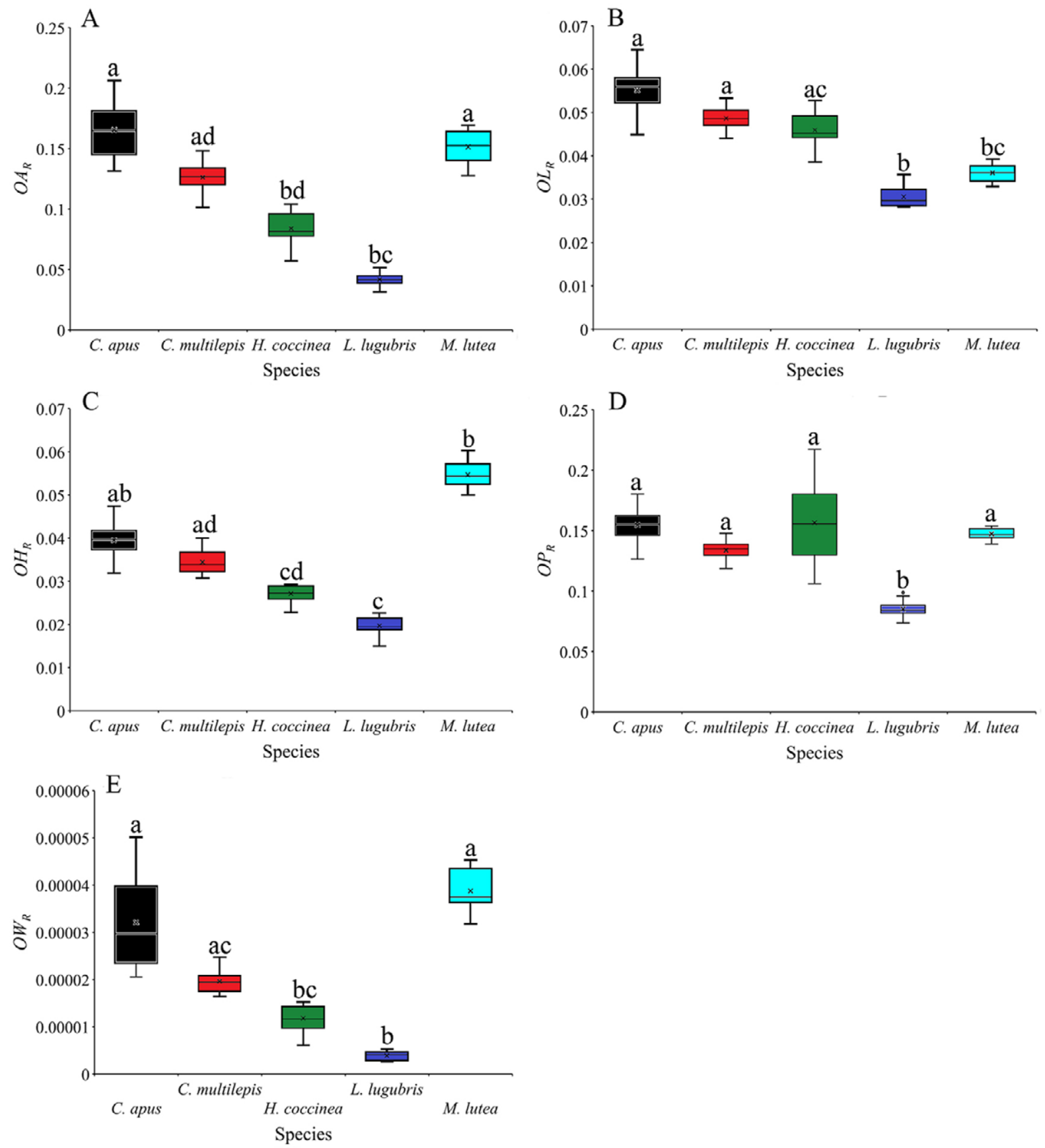

Fig. 5. - Boxplots (maximum. minimum. upper and lower quartiles) for the otolith relative size $\left(O A_{R}\right.$, relative otolith area; $O H_{R}$, relative otolith height; $O L_{R}$, relative otolith length; $O P_{R}$, relative otolith perimeter; $O W_{R}$, relative otolith weight) for the five most common deep-sea benthic anglerfishes from the Andaman and Nicobar Islands. Results of the pairwise comparison using Dunn's post-hoc test (Bonferroni) indicated in different letters. Similar letters indicate no significant difference $(p<0.05)$.

tained for $O H_{R}$ and the lowest for $O P_{R}$. No particular clustering was noted between species. In general, $L$. lugubris showed the lowest values for all relative sizes and $C$. apus the highest ones.

\section{Comparing the functional niches}

The first five PCA axes explained $97.9 \%$ of the total variance and the first three explained $93.8 \%$. The PC1 axis alone contributed $63.7 \%$ of the total variance and was mainly correlated with $F s b(r=0.868)$
(Appendix 4). The positive values represented species with a more dorso-ventrally flattened body and higher swimming capabilities (M. lutea, $H$. coccinea and $L$. lugubris) versus species with higher body depth and lesser swimming abilities (C. multilepis and C. apus) (Fig. 6). The PC2 axis (19.1\% of variance) was related to propulsion and acceleration capabilities ( $A r C F$, $r=0.893$ ), showing a similar pattern in all five species. The PC 3 axis (10.9\% of variance) was mainly related to swimming performance (Arcf, $r=-0.834$ ). The remaining PC scores (4 to 11) cumulatively ex- 
Table 2. - Pairwise comparison of the five most common deep-sea benthic anglerfishes from the Andaman and Nicobar Islands (eastern Indian Ocean) using Dunn's test (Bonferroni, $p<0.001$ ). $O A_{R}$, relative otolith area; $O H_{R}$, relative otolith height; $O L_{R}$, relative otolith length; $O P_{R}$, relative otolith perimeter; $O W_{R}$, relative otolith weight. Statistically significant differences are indicated in bold $(p<0.001)$.

\begin{tabular}{|c|c|c|c|c|c|}
\hline Variable & Species & Chaunax multilepis & Halieutaea coccinea & Lophiodes lugubris & Malthopsis lutea \\
\hline \multicolumn{6}{|l|}{$O A_{R}$} \\
\hline & Chaunax apus & 0.1333 & 0.000 & 0.000 & 1.000 \\
\hline & Chaunax multilepis & & 0.312 & 0.000 & 0.467 \\
\hline & Halieutaea coccinea & & & 0.492 & 0.001 \\
\hline & Lophiodes lugubris & & & & 0.000 \\
\hline \multirow{4}{*}{$O H_{R}$} & Chaunax apus & 1.000 & 0.018 & 0.000 & 1.000 \\
\hline & Chaunax multilepis & & 0.262 & 0.000 & 0.021 \\
\hline & Halieutaea coccinea & & & 0.543 & 0.000 \\
\hline & Lophiodes lugubris & & & & 0.000 \\
\hline \multirow{4}{*}{$O L_{R}$} & Chaunax apus & 0.969 & 0.156 & 0.000 & 0.000 \\
\hline & Chaunax multilepis & & 1.000 & 0.000 & 0.006 \\
\hline & Halieutaea coccinea & & & 0.000 & 0.167 \\
\hline & Lophiodes lugubris & & & & 0.999 \\
\hline \multirow{4}{*}{$O P_{R}$} & Chaunax apus & 0.066 & 1.000 & 0.000 & 1.000 \\
\hline & Chaunax multilepis & & 0.206 & 0.024 & 0.315 \\
\hline & Halieutaea coccinea & & & 0.000 & 1.000 \\
\hline & Lophiodes lugubris & & & & 0.000 \\
\hline \multirow{4}{*}{$O W_{R}$} & Chaunax apus & 0.443 & 0.002 & 0.000 & 1.000 \\
\hline & Chaunax multilepis & & 0.371 & 0.000 & 0.052 \\
\hline & Halieutaea coccinea & & & 0.543 & 0.000 \\
\hline & Lophiodes lugubris & & & & 0.000 \\
\hline
\end{tabular}

plained $6.2 \%$ of the variance and were related to locomotion traits (Appendix 4). MANOVA confirmed the occurrence of significant differences among these deep-sea anglerfishes (Wilk's Lambda=00.0023, $\left.F_{44,258.3}=22.88, p<0.001\right)$. The pairwise comparisons among species using sequential Bonferroni correction indicated significance differences among all species $(p<0.001)$ (Appendix 5).

The functional traits Ops, Edst and Eps showed the highest interspecific differences, whereas $O s f, C p t$ and Fsr showed the lowest (Table 3, Fig. 7). The overall niche overlap ranged between 0.32 for $C$. apus-M. lutea and 0.65 for H. coccinea-L. lugubris. The species with highest niche partitioning was $M$. lutea due to its differentiation in the variables such as Osf, Ops, Edst and Eps. The analysis revealed significant differences between species, with $M$. lutea having a more differentiated functional niche, and both species of Chaunax showed more resemblance between them (Table 4). In any case, the findings indicated that functional niches did not overlap among the common five anglerfishes from the Indian Ocean.

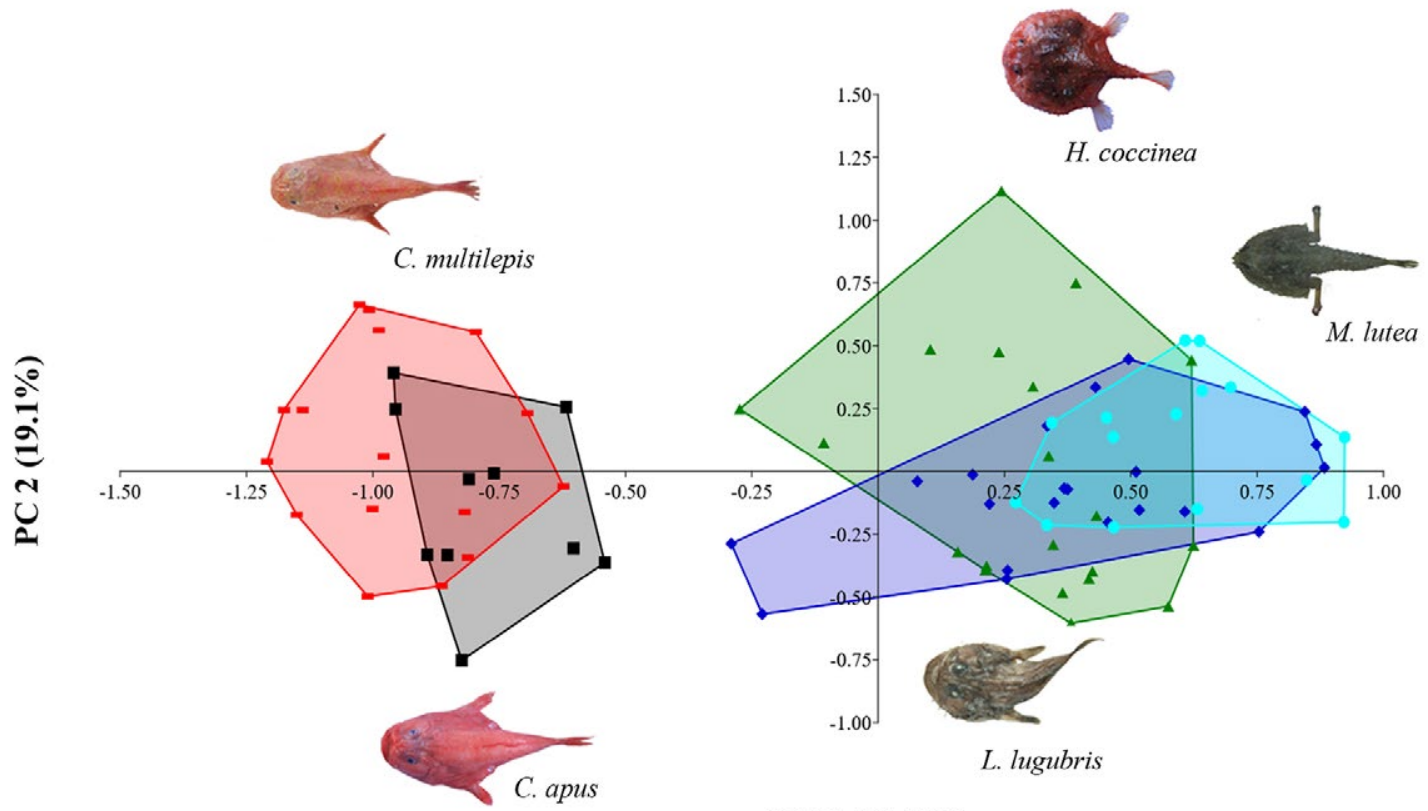

PC $1(63.7 \%)$

Fig. 6. - Functional space from principal component analysis for body shape of the five most common deep-sea benthic anglerfishes from the Andaman and Nicobar Islands (eastern Indian Ocean). 
Table 3. - Estimation of niche overlap (NO) for the functional traits considered of the five most common deep-sea benthic anglerfishes from the Andaman and Nicobar Islands (eastern Indian Ocean). Statistically different niches are indicated in bold $(p<0.05)$. The meaning of traits are explained in the text.

\begin{tabular}{|c|c|c|c|c|c|}
\hline Traits & Species & Chaunax multilepis & Halieutaea coccinea & Lophiodes lugubris & Malthopsis lutea \\
\hline \multicolumn{6}{|l|}{$A r C F$} \\
\hline & Chaunax apus & 0.86 & 0.73 & 0.50 & 0.72 \\
\hline & Chaunax multilepis & & 0.69 & 0.45 & 0.62 \\
\hline & Halieutaea coccinea & & & 0.54 & 0.61 \\
\hline & Lophiodes lugubris & & & & 0.66 \\
\hline \multirow{4}{*}{$A r P F$} & Chaunax apus & 0.56 & 0.44 & 0.26 & 0.13 \\
\hline & Chaunax multilepis & & 0.82 & 0.64 & 0.48 \\
\hline & Halieutaea coccinea & & & 0.75 & 0.57 \\
\hline & Lophiodes lugubris & & & & 0.81 \\
\hline \multirow{4}{*}{ Bsh } & Chaunax apus & 0.61 & 0.00 & 0.04 & 0.00 \\
\hline & Chaunax multilepis & & 0.00 & 0.00 & 0.00 \\
\hline & Halieutaea coccinea & & & 0.80 & 0.47 \\
\hline & Lophiodes lugubris & & & & 0.45 \\
\hline \multirow{4}{*}{ Cpt } & Chaunax apus & 0.61 & 0.72 & 0.66 & 0.71 \\
\hline & Chaunax multilepis & & 0.77 & 0.40 & 0.47 \\
\hline & Halieutaea coccinea & & & 0.61 & 0.67 \\
\hline & Lophiodes lugubris & & & & 0.82 \\
\hline \multirow{4}{*}{ Edst } & Chaunax apus & 0.28 & 0.48 & 0.10 & 0.00 \\
\hline & Chaunax multilepis & & 0.71 & 0.28 & 0.04 \\
\hline & Halieutaea coccinea & & & 0.36 & 0.10 \\
\hline & Lophiodes lugubris & & & & 0.54 \\
\hline \multirow{4}{*}{ Eps } & Chaunax apus & 0.22 & 0.45 & 0.36 & 0.04 \\
\hline & Chaunax multilepis & & 0.67 & 0.53 & 0.40 \\
\hline & Halieutaea coccinea & & & 0.80 & 0.47 \\
\hline & Lophiodes lugubris & & & & 0.51 \\
\hline \multirow{4}{*}{ Fsb } & Chaunax apus & 0.42 & 0.00 & 0.06 & 0.00 \\
\hline & Chaunax multilepis & & 0.00 & 0.01 & 0.00 \\
\hline & Halieutaea coccinea & & & 0.78 & 0.52 \\
\hline & Lophiodes lugubris & & & & 0.62 \\
\hline \multirow{4}{*}{ Fsr } & Chaunax apus & 0.72 & 0.49 & 0.78 & 0.75 \\
\hline & Chaunax multilepis & & 0.74 & 0.91 & 0.91 \\
\hline & Halieutaea coccinea & & & 0.68 & 0.72 \\
\hline & Lophiodes lugubris & & & & 0.90 \\
\hline \multirow{4}{*}{ Ops } & Chaunax apus & 0.20 & 0.83 & 0.57 & 0.25 \\
\hline & Chaunax multilepis & & 0.21 & 0.38 & 0.56 \\
\hline & Halieutaea coccinea & & & 0.57 & 0.29 \\
\hline & Lophiodes lugubris & & & & 0.38 \\
\hline \multirow{4}{*}{$O s f$} & Chaunax apus & 073 & 091 & 081 & 0.20 \\
\hline & Chaunax multilepis & & 0.75 & 0.74 & 0.27 \\
\hline & Halieutaea coccinea & & & 0.76 & 0.14 \\
\hline & Lophiodes lugubris & & & & 0.22 \\
\hline \multirow{4}{*}{ Osh } & Chauna ария & 065 & & & 068 \\
\hline & Chaunax multilepis & & 0.87 & 0.38 & 0.40 \\
\hline & Halieutaea coccinea & & & 0.46 & 0.49 \\
\hline & Lophiodes lugubris & & & & 0.84 \\
\hline
\end{tabular}

Table 4. - Average (and standard deviation) weighed niche overlap for the functional traits considered between each pair of the five most common deep-sea benthic anglerfishes from the Andaman and Nicobar Islands (eastern Indian Ocean). Statistically different niches are indicated in bold $(p<0.001)$.

\begin{tabular}{lccc}
\hline Species & Chaunax multilepis & Halieutaea coccinea & Lophiodes lugubris \\
\hline Chaunax apus & $\mathbf{0 . 5 3 ( \mathbf { 0 . 2 2 } )}$ & $\mathbf{0 . 5 2}(\mathbf{0 . 3 0})$ & $\mathbf{0 . 4 4}(\mathbf{0 . 2 9})$ \\
Chaunax multilepis & $\mathbf{0 . 5 7}(\mathbf{0 . 3 3})$ & $\mathbf{0 . 4 3}(\mathbf{0 . 2 8})$ & $\mathbf{0 . 3 2}(\mathbf{0 . 3 3})$ \\
Halieutaea coccinea & & $\mathbf{0 . 1 5})$ \\
Lophiodes lugubris & & $\mathbf{0 . 4 6}(\mathbf{0 . 2 8})$ & $\mathbf{0 . 2 0})$ \\
\hline
\end{tabular}

\section{DISCUSSION}

Most studies performed on deep-sea fish species from Indian waters have focused on taxonomy and biology (Karuppasamy et al. 2008, Sreedhar et al. 2013,
Kumar et al. 2016, 2018), and only few have analysed interspecific competition (Narayani et al. 2015, Kumar et al. 2017a). The present study delved into this matter by analysing the differences in the sensory capability and functional niche of most common anglerfishes 
378 - M. Rajeeshkumar et al.
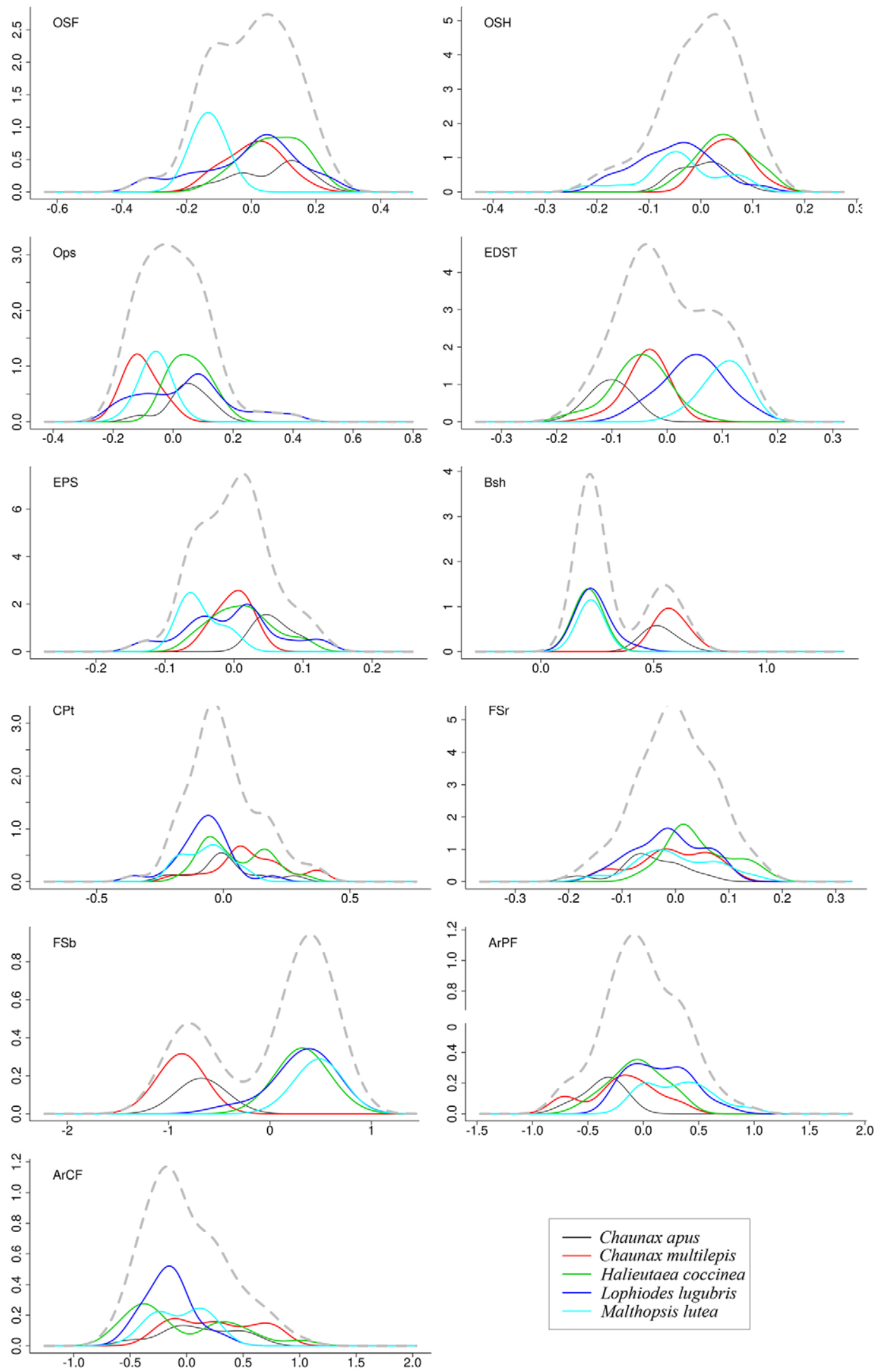

Fig. 7. - Species density distributions ( $\mathrm{y}$-axis) using kernel density models for each functional trait ( $\mathrm{x}$-axis) for the five most common deep-sea benthic anglerfishes from the Andaman and Nicobar Islands (eastern Indian Ocean). Grey dashed line indicates the total density for all species. $A R C F$, aspect ratio of the caudal fin; $A R P F$, aspect ratio of the pectoral fin; $B s h$, body transversal shape; $C p t$, caudal peduncle throttling; $E d s t$, eye size; Eps, eye position; $F s b$, fins surface to body size ratio; $F s r$, fins surface ratio; $O s f$, oral gape surface; $O s h$, oral gape shape; $O p s$, oral gape position. 
inhabiting these waters. In this context, our findings revealed a strong environmental adaptation of sagitta otolith shape to the depth distribution of species, confirming the ecomorphological pattern proposed by Colmenero et al. (2010) for Lophius spp. from the Mediterranean Sea. Moreover, the dissimilarity between the functional niches indicated a low interspecific niche overlap. Finally, no phylogenetic influence was inferred from the morpho-functional features analysed, as occurs in other fish species (Tuset et al. 2010, 2018, Kéver et al. 2014, Schwarzhans 2014), although a greater number of taxa should be necessary for this purpose.

The relative size of fish otoliths tends to increase with depth (Lombarte and Cruz 2007), improving their hearing capacities to compensate for the limitation in visual communication (Lychakov and Rebane 2000, Paxton 2000, Tuset et al. 2018). However, this trend is reversed due to carbonate under-saturation below 1000 m depth (Wilson 1985, Lombarte and Cruz 2007). This ecomorphological pattern was found in the present study: Chaunax spp. and M. lutea, characterized by a wide bathymetric distribution (200-700 m; Ho et al. 2016a, Rajeeshkumar 2018), had a greater relative otolith size in the area, height and weight; L. lugubris, the shallowest species $(<250 \mathrm{~m}$; Alcock 1894, Ho et al. 2016a, Rajeeshkumar 2018), had a smaller relative otolith size; and $H$. coccinea, which can inhabit over $>1000$ m (Rajeeshkumar 2018), also reached low values for some relative otolith sizes. Certainly, the set of relative otolith indices did not follow the same trend, which may be due to the high irregularity of sculpture of the dorsal margin in anglerfishes (see more examples in AFORO website, http://aforo.cmima.csic.es/; Lombarte et al. 2006; present study). It is known that this variability occurs at inter- and intraspecific levels and is a disadvantage for the automated separation of stocks (example in Cañás et al. 2012) and for the identification of species. Moreover, it would explain the low coefficients of determination and the interspecific similarity obtained in the slope value $(b)$ of some morphometric relationships. Although some studies have demonstrated a morpho-functional correlation between the otolith and fish body shapes (Volpedo et al. 2008, Mille et al. 2016, Tuset et al. 2018), we found no evidence that the morphometry, relative otolith size and sculpture of the otolith margins were associated with the fish body morphotypes (globose versus dorsoventrally flattened) or had any phylogenetic meaning in anglerfishes.

Given that common anglerfishes from the Indian Ocean had different functional niches and can coexist in some bathymetries, the slight variations in their functional traits suggest that functional variability is linked to competence for similar resource requirements (theory of limiting similarity, MacArthur and Levins 1967), as occurs in other fish groups such as cichlids (Winemiller et al. 1995), labrids (Wainwright et al. 2002), butterflyfishes (Bellwood et al. 2010), notothenids (Lombarte et al. 2010), rockfishes (Ingram 2011), damselfishes (Frederich et al. 2016) and lanternfishes (Tuset et al. 2018). Anglerfishes with a dorso-ventrally flattened body ( $M$. lutea, L. lugubris and H. coccinea) were characterized by a higher swimming efficiency in relation to species with globose body (Chaunax spp.). However, unlike $M$. lutea and $H$. coccinea, both L. lugubris and Chaunax spp. attract their prey with an angling apparatus (or illicium), which has a bait (esca) in the case of Chaunax spp. (Pietsch and Grobecker 1987, Armstrong et al. 1996, Ho et al. 2016a). This bait facilitates a predator behaviour based on slow movements by waiting for the potential prey very close to the mouth, whereas the greater swimming ability of L. lugubris would indicate the possibility of capturing prey more actively (i.e. at a greater distance from its prey).

Overall, anglerfishes with higher swimming capability and oral gape surface (e.g., L. lugubris and $H$. coccinea) seem to ingest more mobile and larger prey, including fishes (Zhao et al. 2014, Kumar et al. 2017a), whereas those with lesser swimming abilities or a smaller oral gape select crustaceans and gastropods as the main potentially preys (Gibran and Castro 1999, Karuppasamy et al. 2008, Nagareda and Shenker 2008). Although the theory on the resource partitioning among the species in deep-sea habitats is essentially based on prey size and swimming capacity near the bottom (Papiol et al. 2013, Kumar et al. 2017a), species can also differentiate their feeding rhythms (nocturnal or diurnal). The ability to be more active at night is based on a higher sensory sensitivity from visual and hearing capabilities (Warrant 2004, Schmitz and Wainwright 2011, de Busserolles et al. 2013, Sadighzadeh et al. 2014). Colmenero et al. (2010) concluded that the eye size reflected the nocturnal phenotype between Lophius spp. from the Mediterranean Sea. Our findings suggest a similar behavioural ability in $M$. lutea and $L$. lugubris in relation to the remaining species.

In conclusion, anglerfishes have evolved functionally towards different ecological strategies to live in low-energy habitats. Hence, morpho-functional traits seem to be good ecological predictors for explaining the coexistence of species. Functional traits associated with feeding habits, locomotion and manoeuvrability help us to understand the ecology of these species (Bridge et al. 2016, Kumar et al. 2017a) and to predict their niches (Mouillot et al. 2005, Mason et al. 2008, Zhao et al. 2014). The eyes seem to be crucial for the differentiation of their feeding activity and the otolith for their hearing capabilities (Colmenero et al. 2010).

\section{ACKNOWLEDGEMENTS}

The authors express their sincere thanks and gratitude to the Secretary of the Ministry of Earth Sciences (MoES), New Delhi and the Director of the Centre for Marine Living Resources and Ecology (MoES), Government of India, for supporting the work and providing the facilities onboard FORV Sagar Sampada for the sample collection. We are very grateful to the chief scientists, fishing master, fishing hands and all participants of FORV Sagar Sampada for their excellent cooperation during the cruise (Cr. No. 349). We also express our sincere thanks to William Watson (NOAA) for the critical evaluation of the manuscript, 
which certainly improved its quality. The editorial assistance from N Rajendran (CMLRE) is also thankfully acknowledged. The study was carried out as part of the in-house project "Resource Exploration and Inventorisation Systems" under the Marine Living Resource Programme of CMLRE, MoES. The financial, technical and logistical support from CMLRE is wholeheartedly appreciated. This is CMLRE contribution no 117.

\section{REFERENCES}

Afonso-Dias I.M.D.S.B.R.P. 1997. Aspects of the biology and ecology of anglerfish (Lophius piscatorius) off the west coast of Scotland (ICES sub area via). Ph.D. thesis, Univ. Aberdeen, $192 \mathrm{pp}$.

Aguilar-Medrano R., Frederich B., Barber P.H. 2016. Modular diversification of the locomotor system in damselfishes (Pomacentridae). J. Morphol. 277: 603-614. https://doi.org/10.1002/jmor.20523

Albouy C., Guilhaumon F., Villéger S., et al. 2011. Predicting trophic guild and diet overlap from functional traits: statistics, opportunities and limitations for marine ecology. Mar. Ecol. Prog. Ser. 436: 7-28. https://doi.org/10.3354/meps09240

Alcock A.W. 1891. Natural history notes from H.M. Indian Marine Survey Steamer "Investigator" Ser. II, No. 1. On the results of deep-sea dredging during the season 1890-91. Ann. Mag. Nat. Hist. 6: 16-34. https://doi.org/10.1080/00222939109460385

Alcock A.W. 1894. Natural history notes from H.M. Indian Marine Survey Steamer Investigator'- No. 11. An account of a recent collection of bathybial fishes from the Bay of Bengal and from the Laccadive Sea. J. Asiat. Soc. Bengal 58: 115-140.

Arellano R.V., Hamerlynck O., Vincx M., et al. 1995. Changes in the ratio of the sulcus acusticus area to the sagitta area of Pomatoschistus minutus and P. lozanoi (Pisces, Gobidae). Mar. Biol. 122: $355-360$ https://doi.org/10.1007/BF00350868

Armstrong M.P., Musick J.A., Colvocoresses J.A. 1996. Food and ontogenetic shifts in feeding of the goosefish, Lophius americanus. J. Northwest Atl. Fish. Sci. 18: 99-103. https://doi.org/10.2960/J.v18.a7

Arnold R.J. 2015. Evolutionary Relationships of the Enigmatic Anglerfishes (Teleostei: Lophiiformes): Can Nuclear DNA Provide Resolution for Conflicting Morphological and Mitochondrial Phylogenies? Ph.D. thesis, Univ. Wash. U.S.A., 83 pp.

Arnold R.J., Pietsch T.W. 2012. Evolutionary history of frogfishes (Teleostei: Lophiiformes: Antennariidae): A molecular approach. Mol. Phylogenetics Evol. 62: 117-129. https://doi.org/10.1016/j.ympev.2011.09.012

Balakrishnan M., Srivastava R.C., Pokhriyal M. 2008. Biodiversity of Andaman and Nicobar Islands. Biobytes 3: 9-12.

Bellwood D.R., Klanten S., Cowman P.F., et al. 2010. Evolutionary history of the butterflyfishes (f: Chaetodontidae) and the rise of coral feeding fishes. J. Evol. Biol. 23: 335-349. https://doi.org/10.1111/j.1420-9101.2009.01904.x

Bellwood D.R., Goatley C.H.R., Brandl S.J., et al. 2014. Fifty million years of herbivory on coral reefs: fossils, fish and functional innovations. Proc. R. Soc. B 281: 20133046. https://doi.org/10.1098/rspb.2013.3046

Bohórquez-Herrera J., Cruz-Escalona V.H., Adams D.C., et al. 2015. Feeding ecomorphology of seven demersal marine fish species in the Mexican Pacific Ocean. Environ. Biol. Fish. 98: 1459-1473. https://doi.org/10.1007/s10641-014-0373-1

Boyle K.S., Horn M.H. 2006. Comparison of feeding guild structure and ecomorphology of intertidal fish assemblages from central California and central Chile. Mar. Ecol. Prog. Ser. 319: 65-84. https://doi.org/10.3354/meps319065

Bridge T.C. Luiz O.J., Coleman R.R., et al. 2016. Ecological and morphological traits predict depth-generalist fishes on coral reefs. Proc. R. Soc. B 283: 20152332. https://doi.org/10.1098/rspb.2015.2332

Cañás L., Stransky C., Schlickeisen J., et al. 2012. Use of the otolith shape analysis in stock identification of anglerfish (Lophius piscatorius) in the Northeast Atlantic. ICES J. Mar. Sci. 69: 250-256. https://doi.org/10.1093/icesjms/fss006

Carothers J.H., Jaksić, F.M. 1984. Time as a niche difference: the role of interference competition. Oikos 42: 403-406. https://doi.org/10.2307/3544413

Carlucci R., Capezzuto F., Maiorano P., et al. 2009. Distribution, population structure and dynamics of the black anglerfish (Lophius budegassa) (Spinola, 1987) in the Eastern Mediterranean Sea. Fish. Res. 95: 76-87. https://doi.org/10.1016/j.fishres.2008.07.015

Caruso J.H. 1981. The systematics and distribution of the lophiid anglerfishes: I. A revision of the genus Lophiodes, with the description of two new species. Copeia 3: 522-549.

Caruso J.H. 1983. The systematics and distribution of the lophiid anglerfishes: II. Revisions of the genera Lophiomus and Lophius. Copeia 1: 11-30. https://doi.org/10.2307/1444694

Caruso J.H., 1985. The systematics and distribution of the lophiid anglerfishes: III. Intergeneric relationships. Copeia 4: 870-875. https://doi.org/10.2307/1445235

Caruso J.H. 2002. Order Lophiiformes: Lophiidae. In: Carpenter K.E. (ed.), The Living Marine Resources of the Western Central Atlantic. Food and Agriculture Organization of the United Nations, Rome, pp. 1043-1049.

Casatti L., Castro R. 2006. Testing the ecomorphological hypothesis in a headwater riffles fish assemblage of the rio São Francisco, southeastern Brazil. Neotropical ichthyol. 4: 203-214. https://doi.org/10.1590/S1679-62252006000200006

Colborne S.F., Peres-Neto P.R., Longstaffe F.J., et al. 2013. Effects of foraging and sexual selection on ecomorphology of a fish with alternative reproductive tactics. Behav. Ecol. 24: 1339-1347. https://doi.org/10.1093/beheco/art072

Collar D.C., Wainwright P.C. 2006. Discordance between morphological and mechanical diversity in the feeding mechanism of centrarchid fishes. Evolution 60: 2575-2584. https://doi.org/10.1111/j.0014-3820.2006.tb01891.x

Colmenero A.I., Aguzzi J., Lombarte A., et al. 2010. Sensory constraints in temporal segregation in two species of anglerfish, Lophius budegassa and L. piscatorius. Mar. Ecol. Prog. Ser. 416: $255-265$. https://doi.org/10.3354/meps08766

de Busserolles F., Fitzpatrick J.L., Paxton J.R., et al. 2013. Eye-size variability in deep-sea lanternfishes (Myctophidae): an ecological and phylogenetic study. PLoS ONE 8: e58519. https://doi.org/10.1371/journal.pone.0058519

Foster K., Bower L., Piller K. 2015. Getting in shape: habitat-based morphological divergence for two sympatric species. Biol. J. Linn. Soc. 114: 152-162. https://doi.org/10.1111/bij.12413

Frederich B., Olivier D., et al. 2016. Trophic ecology of damselfishes. In: Frederich B., Parmentier E (eds), Biology of Damselfishes, CRC Press, pp. 153-167. https://doi.org/10.1201/9781315373874

Froese R. 2006. Cube law, condition factor and weight-length relationships: history, meta-analysis and recommendations. J. Appl. Ichthyol. 22: 241-253. https://doi.org/10.1111/j.1439-0426.2006.00805.x

Froese R., Tsikliras A.C., Stergiou K.I. 2011. Editorial note on weight-length relations of fishes. Acta Ichthyol. et Piscatoria 41: 261-263. https://doi.org/10.3750/AIP2011.41.4.01

Gatz A.J. 1979. Community organization in fishes as indicated by morphological features. Ecology 60: 711-718. https://doi.org/10.2307/1936608

Geange S.W., Pledger S., Burns K.C., et al. 2011. A unified analysis of niche overlap incorporating data of different types. Methods Ecol. Evol. 2: 175-184. https://doi.org/10.1111/j.2041-210X.2010.00070.x

Gibran F.Z., Castro R.M.C. 1999. Activity, feeding behaviour and diet of Ogcocephalus vespertilio in southern west Atlantic. J. Fish Biol. 55: 588-595. https://doi.org/10.1111/j.1095-8649.1999.tb00701.x

Hammer O., Harper D.A.T., Ryan P.D. 2001. PAST: Paleontological Statistic software package for education and data analysis. Paleontol. Electron. 4: 4 https://palaeo-electronica.org/2001_1/past/past.pdf

Hashim M. 2012. Distribution, diversity and biology of deep-sea fishes in the Indian EEZ. Ph.D. thesis, Cochin Univ. Sci. Technol. India, $131 \mathrm{pp}$.

Hislop J.R.G., Holst J.C., Skagen D. 2000. Near-surface captures of 
post-juvenile anglerfish in the North-east Atlantic-an unsolved mystery. J. Fish Biol. 57: 1083-1087.

https://doi.org/10.1111/j.1095-8649.2000.tb02214.x

Ho H.C., Ma W.C. 2016. Revision of southern African species of the anglerfish genus Chaunax (Lophiiformes: Chaunacidae), with descriptions of three new species. Zootaxa 4144: 175-194. https://doi.org/10.11646/zootaxa.4144.2.2

Ho H.C., Shao K.T. 2008. The batfishes (Lophiiformes Ogcocephalidae) of Taiwan, with descriptions of eight new records. J. Fish Soc. Taiwan 35: 289-313.

Ho H.C., Meleppura R.K., Bineesh K.K. 2016a. Chaunax multilepis sp. nov., a new species of Chaunax (Lophiiformes: Chaunacidae) from the northern Indian Ocean. Zootaxa 4103: 130-136. https://doi.org/10.11646/zootaxa.4103.2.3

Ho H.C., Kawai T., Satria F. 2016b. New records of the anglerfish family Lophiidae (Order Lophiiformes) from Indonesia. Acta Ichthyol. et Piscatoria 46: 77-85. https://doi.org/10.3750/AIP2016.46.2.03

Huxley J.S. 1924. Constant differential growth-ratios and their significance. Nature 114: 895-896. https://doi.org/10.1038/114895a0

Ingram T. 2011. Speciation along a depth gradient in a marine adaptive radiation. Proc. R. Soc. B 278: 613-618. https://doi.org/10.1098/rspb.2010.1127

Jayaprakash A.A., Kurup B.M., Sreedhar U., et al. 2006. Distribution, diversity, length-weight relationship and recruitment pattern of deep-sea finfishes and shell fishes in the shelf-break area off southwest Indian EEZ. J. Mar. Biol. Assoc. India 48: 56-67.

Karpouzi V.S., Stergiou K.I. 2003. The relationships between mouth size and shape and body length for 18 species of marine fishes and their trophic implications. J. Fish Biol. 62: 1353-1365. https://doi.org/10.1046/j.1095-8649.2003.00118.x

Karuppasamy P.K., Balachandran K., George S., et al. 2008. Food of some deep sea fishes collected from the eastern Arabian Sea. J. Mar. Biol. Assoc. India 50: 134-138.

Kéver L., Colleye O., Herrel A., et al. 2014. Hearing capacities and otolith size in two ophidiiform species (Ophidion rochei and Carapus acus). J. Exp. Biol. 217: 2517-2525. https://doi.org/10.1242/jeb.105254

Kumar K.V.A., Thomy R., Deepa K.P., et al. 2016. Length-weight relationship of six deep-sea fish species from the shelf regions of western Bay of Bengal and Andaman waters. J. Appl. Ichthyol. 32: 1334-1336. https://doi.org/10.1111/jai.13164

Kumar K.V.A., Tuset V.M., Manjebrayakath H., et al. 2017a. Functional approach reveals low niche overlap among common deep-sea fishes from the south-eastern Arabian Sea. Deep Sea Res. I 119: 16-23. https://doi.org/10.1016/j.dsr.2016.11.011

Kumar K.V.A., Nikki R., Oxona K., et al. 2017b. Relationships between fish and otolith size of nine deep-sea fishes from the Andaman and Nicobar waters. North Indian Ocean. J. Appl. Ichthyol. 33: 1187-1195. https://doi.org/10.1111/jai.13467

Kumar K.V.A., Deepa K.P., Hashim M., et al. 2017c. Relationships between fish size and otolith size of four bathydemersal fish species from the south eastern Arabian Sea, India. J. Appl. Ichthyol. 33: 102-107. https://doi.org/10.1111/jai.13250

Kumar K.V.A., Thomy R., Hashim M., et al. 2018. Length-weight relationships of 11 deep-sea fishes from the western Bay of Bengal and Andaman waters, India. J. Appl. Ichthyol. 34: 1048-1051. https://doi.org/10.1111/jai.13695

Layman C.A., Langerhans R.B., Winemiller K.O. 2005. Body size, not other morphological traits, characterizes cascading effects in fish assemblage composition following commercial netting. Can. J. Fish. Aquat. Sci. 62: 2802-2810. https://doi.org/10.1139/f05-183

Lleonart J., Salat J., Torres G.J. 2000. Removing allometric effects of body size in morphological analysis. J. Theor. Biol. 205: $85-93$. https://doi.org/10.1006/jtbi.2000.2043

Lloyd R.E. 1909. A description of the deep-sea fish caught by the RIMS ship" Investigator" since the year 1900, with supposed evidence of mutation in Malthopsis. Mem. Indian Mus. 2: $139-180$.

Lombarte A. 1992. Changes in otolith area: sensory area ratio with body size and depth. Environ. Biol. Fish. 33: 405-410. https://doi.org/10.1007/BF00010955
Lombarte A., Cruz A. 2007. Otolith size trends in marine fish communities from different depth strata. J. Fish Biol. 71: 53-76. https://doi.org/10.1111/j.1095-8649.2007.01465.x

Lombarte A., Chic Ò., Parisi-Baradad V., et al. 2006. A web-based environment for shape analysis of fish otoliths. The AFORO database. Sci. Mar. 70: 147-152. https://doi.org/10.1007/BF00010955

Lombarte A., Palmer M., Matallanas J., et al. 2010. Ecomorphological trends and phylogenetic inertia of otolith sagittae in Nototheniidae. Environ. Biol. Fish. 89: 607-618. https://doi.org/10.1007/s10641-010-9673-2

Lychakov D.V., Rebane Y.T. 2000. Otolith regularities. Hear. Res. 143: 83-102. https://doi.org/10.1016/S0378-5955(00)00026-5

MacArthur R., Levins R. 1967. The limiting similarity, convergence, and divergence of coexisting species. Am. Nat. 101: 377-385. https://doi.org/10.1086/282505

Marrama G., Kriwet J. 2017. Principal component and discriminant analyses as powerful tools to support taxonomic identification and their use for functional and phylogenetic signal detection of isolated fossil shark teeth. Plos ONE 12: e0188806. https://doi.org/10.1371/journal.pone.0188806

Marcus L.F. 1993. Some aspects of multivariate statistics for morphometrics. In: Marcus L.F., Bello E., et al. (eds), Contributions to morphometrics. Monog. Mus. Nac. Cienc. Nat. 8: 95-130.

Mason N.W., Lanoiselée C., Mouillot D., et al. 2008. Does niche overlap control relative abundance in French lacustrine fish communities? A new method incorporating functional traits. J. Anim. Ecol. 77: 661-669. https://doi.org/10.1111/j.1365-2656.2008.01379.x

Mille T., Mahe K., Cachera M., et al. 2016. Diet is correlated with otolith shape in marine fish. Mar. Ecol. Prog. Ser. 555: 167-184. https://doi.org/10.3354/meps 11784

Miya M., Pietsch T.W., Orr J.W., et al. 2010. Evolutionary history of anglerfishes (Teleostei: Lophiiformes): a mitogenomic perspective. BMC Evol. Biol. 10: 58 https://doi.org/10.1186/1471-2148-10-58

Mouillot D., Mason W.N., Dumay O., et al. 2005. Functional regularity: a neglected aspect of functional diversity. Oecologia 142: 353-359. https://doi.org/10.1007/s00442-004-1744-7

Mouillot D., Graham N.A., Villéger S., et al. 2013. A functional approach reveals community responses to disturbances. Trends Ecol. Evol. 28: 167-177. https://doi.org/10.1016/j.tree.2012.10.004

Nagareda B.H., Shenker J.M. 2008. Dietary analysis of batfishes (Lophiiformes: Ogcocephalidae) in the Gulf of Mexico. Gulf Mexico Sci. 26: 28-35. https://doi.org/10.18785/goms.2601.03

Narayani S., Venu S., Kumar M.A. et al. 2015. Ecomorphology of the feeding characteristics in selected reef fishes from south Andaman Islands: a preliminary study. J. Mar. Biol. Oceanogr. 4: $1-7$ https://doi.org/10.4172/2324-8661.1000145

Nazir A., Khan M.A. 2019. Spatial and temporal variation in otolith chemistry and its relationship with water chemistry: Stock discrimination of Sperata aor. Ecol. Freshwater Fish 28: 499-511. https://doi.org/10.1111/eff.12471

Nelson J.S., Grande T.C., Wilson M.V.H. 2006. Fishes of the world. John Wiley and Sons, New Jersey, $707 \mathrm{pp}$

Papiol V., Cartes J.E., Fanelli E., et al. 2013. Food web structure and seasonality of slope megafauna in the NW Mediterranean elucidated by stable isotopes: relationship with available food sources. J. Sea Res. 77: 53-69. https://doi.org/10.1016/j.seares.2012.10.002

Paxton J.R. 2000. Fish otoliths: do sizes correlate with taxonomic group, habitat and/or luminescence? Philos. Trans. R. Soc. Lond. B. 355: 1299-1303. https://doi.org/10.1098/rstb.2000.0688

Pietsch T.W. 1981. The osteology and relationships of the anglerfish genus Tetrabrachium with comments on lophiiform classification. Fish. Bull. 79: 387-419.

Pietsch T.W., Grobecker D.B. 1987. Frogfishes of the world: systematics, zoogeography, and behavioral ecology. Stanford University Press, $420 \mathrm{pp}$.

Pietsch T.W., Orr J.W. 2007. Phylogenetic relationships of deepsea anglerfishes of the suborder Ceratioidei (Teleostei: Lophiiformes) based on morphology. Copeia 2007: 1-34. https://doi.org/10.1643/0045-8511(2007)7[1:PRODAO]2.0.CO;2

Pohlert T. 2014. The pairwise multiple comparison of mean ranks 
package (PMCMR). R package, $27 \mathrm{pp}$.

https://cran.r-project.org/web/packages/PMCMR/vignettes/ PMCMR.pdf

Preciado I., Velasco F., Olaso I., et al. 2006. Feeding ecology of black anglerfish Lophius budegassa: seasonal, bathymetric and ontogenetic shifts. J. Mar. Biol. Assoc. U.K. 86: 877-884. https://doi.org/10.1017/S0025315406013816

Quinn G.P., Keough M.J. 2002. Experimental Design and Data Analysis for Biologists, Cambridge University Press, Cambridge, $558 \mathrm{pp}$. https://doi.org/10.1017/CBO9780511806384

R Development Core Team. 2017. R: A language and environment for statistical computing. R Foundation for Statistical Computing, Vienna, Austria. http://www.Rproject.org/

Rajan P.T., Sreeraj C.R. 2013. Fish fauna of Andaman and Nicobar Islands: a review. In: Venkataraman K., Sivaperuman C., et al. (eds), Ecology and Conservation of Tropical Marine Faunal Communities. Springer, Berlin, Heidelberg, pp. 231-243. https://doi.org/10.1007/978-3-642-38200-0_15

Rajeeshkumar M.P. 2018. Deep-sea anglerfishes (Pisces-Lophiiformes) of the Indian EEZ: Systematics, distribution and Biology. Ph.D. thesis, Cochin Univ. Sci. Technol. India, 307 pp.

Rajeeshkumar M.P., Jacob V., Sumod K.S., et al. 2016. Three new records of rare deep-sea Anglerfishes (Lophiiformes: Ceratioidei) from the Northern Indian Ocean. Mar. Biodivers. 46: 923-928. https://doi.org/10.1007/s12526-015-0437-2

Rajeeshkumar M.P., Meera K.M. Hashim M. 2017. A New Species of the Deep-Sea Ceratioid Anglerfish Genus Oneirodes (Lophiiformes: Oneirodidae) from the Western Indian Ocean Copeia 105: 82-84 https://doi.org/10.1643/CI-16-467

Ribeiro M.D., Teresa F.B., Casatti L. 2016. Use of functional traits to assess changes in stream fish assemblages across a habitat gradient. Neotropical Ichthyol. 14: e140185. https://doi.org/10.1590/1982-0224-20140185

Sadighzadeh Z., Otero-Ferrer J.L., Lombarte A., et al. 2014. An approach to unraveling the coexistence of snappers (Lutjanidae) using otolith morphology. Sci. Mar. 78: 353-362. https://doi.org/10.3989/scimar.03982.16C

Schmitz L., Wainwright P.C. 2011. Nocturnality constrains morphological and functional diversity in the eyes of reef fishes. BMC Evol. Biol. 11: 338 https://doi.org/10.1186/1471-2148-11-338

Schwarzhans W. 2014. Head and otolith morphology of the genera Hymenocephalus, Hymenogadus and Spicomacrurus (Macrouridae), with the description of three new species. Zootaxa 3888: 73 pp. https://doi.org/10.11646/zootaxa.3888.1.1

Seehausen O., Terai Y., Magalhaes I.S., et al. 2008. Speciation through sensory drive in cichlid fish. Nature 455: 620-626. https://doi.org/10.1038/nature07285

Sibbing F.A., Nagelkerke L.A.J. 2001. Resource partitioning by lake Tana barbs predicted from fish morphometrics and prey characteristics. Rev. Fish. Biol. Fish. 10: 393-437. https://doi.org/10.1023/A:1012270422092

Sreedhar U., Sudhakar G.V.S., Meenakumari B. 2013. Lengthweight relationship of deepsea demersal fishes from the Indian EEZ. Ind. J. Fish. 60: 123-125.

Sumod K.S. 2018. Deep-sea eels (Teleostei: Anguilliformes) of Indian EEZ: Systematics, distribution and Biology. Ph.D. thesis, Cochin Univ. Sci. Technol. India, 474 pp.

Tuset V.M., Lombarte A., Assis C.A. 2008. Otolith atlas for the western Mediterranean, north and central eastern Atlantic. Sci. Mar. 72S1: 7-198.

https://doi.org/10.3989/scimar.2008.72s17

Tuset V.M., Piretti S., Lombarte A., et al. 2010. Using sagittal otoliths and eye diameter for ecological characterization of deepsea fish: Aphanopus carbo and A. intermedius from NE Atlantic waters. Sci. Mar. 74: 807-814. https://doi.org/10.3989/scimar.2010.74n4807

Tuset V.M., Otero-Ferrer J.L., Gómez-Zurita J., et al. 2016. Otolith shape lends support to the sensory drive hypothesis in rockfishes. J. Evol. Biol. 29: 2083-2097. https://doi.org/10.1111/jeb.12932

Tuset V.M., Olivar M.P., Otero-Ferrer J.L., et al. 2018. Morphofunctional diversity in Diaphus spp. (Pisces: Myctophidae) from the central Atlantic Ocean: Ecological and evolutionary implications. Deep Sea Res. I 138: 46-59. https://doi.org/10.1016/j.dsr.2018.07.005

Venu S., Kurup B.M. 2002. Distribution and abundance of deep-sea fishes along the west coast of India. Fish Technol. 39: 20-26.

Villéger S., Novack-Gottshall P.M., Mouillot D. 2011. The multidimensionality of the niche reveals functional diversity changes in benthic marine biotas across geological time. Ecol. Lett. 14: 561-568. https://doi.org/10.1111/j.1461-0248.2011.01618.x

Villéger S., Brosse S., Mouchet M., et al. 2017. Functional ecology of fish: current approaches and future challenges. Aquat. Sci. 79: 783-801. https://doi.org/10.1007/s00027-017-0546-Z

Volpedo A.V., Tombari A.D., Echeverría D.D. 2008. Ecomorphological patterns of the sagitta of Antarctic fish. Polar Biol. 31: 635-640. https://doi.org/10.1007/s00300-007-0400-1

Wainwright P.C., Bellwood D.R., Westneat M.W. 2002. Ecomorphology of locomotion in labrid fishes. Environ. Biol. Fish. 65: 47-62. https://doi.org/10.1023/A:1019671131001

Wainwright P., Carroll A.M., Collar D.C., et al. 2007. Suction feeding mechanics, performance, and diversity in fishes. Integr. Comp. Biol. 47: 96-106. https://doi.org/10.1093/icb/icm032

Warrant E. 2004. Vision in the dimmest habitats on earth. J. Comp. Physiol. A 190: 765-789. https://doi.org/10.1007/s00359-004-0546-z

Watson D.J., Balon E.K. 1984. Ecomorphological analysis of fish taxocenes in rainforest streams of northern Borneo. J. Fish Biol. 25: 371-384. https://doi.org/10.1111/j.1095-8649.1984.tb04885.x

Webb P.W. 1984. Body form, locomotion and foraging in aquatic vertebrates. Am. Zool. 24: 107-120. https://doi.org/10.1093/icb/24.1.107

Wilson Jr. R.R. 1985. Depth-related changes in sagitta morphology in six macrourid fishes of the Pacific and Atlantic Oceans. Copeia 4: 1011-1017. https://doi.org/10.2307/1445256

Winemiller K.O., Kelso-Winemiller L.C., Brenkert A.L. 1995. Ecomorphological diversification and convergence in fluvial cichlid fishes. In: Luczkovich J.J., Motta P.J., et al. (eds), Ecomorphology of fishes. Springer, Dordrecht, pp. 235-261. https://doi.org/10.1007/978-94-017-1356-6_17

Zhao T. Villéger S., Lek S., et al. 2014. High intraspecific variability in the functional niche of a predator is associated with ontogenetic shift and individual specialization. Ecol. Evol. 4: 4649-4657.

https://doi.org/10.1002/ece3.1260 


\section{APPENDICES}

Appendix 1. - Descriptive values of fish length and otolith measurements of the five most common deep-sea benthic anglerfishes from the Andaman and Nicobar Islands (eastern Indian Ocean). min, minimum; max, maximum; n, number of specimens; $O A$, otolith area; $O H$, otolith height; $O L$, otolith length; $O P$, otolith perimeter; $O W$, otolith weight; sd, standard deviation; $S L$, standard length.

\begin{tabular}{|c|c|c|c|c|c|c|}
\hline Species & Variables & $\mathrm{n}$ & $\min$ & $\max$ & mean & sd \\
\hline Chaunax apus & $\begin{array}{l}O A \\
O H \\
O L \\
O P \\
O W \\
S L\end{array}$ & 10 & $\begin{array}{c}12.3 \\
3.47 \\
4.86 \\
13.2 \\
0.022 \\
59\end{array}$ & $\begin{array}{c}35 \\
5.53 \\
7.93 \\
23.4 \\
0.099 \\
155\end{array}$ & $\begin{array}{c}19.15 \\
4.19 \\
5.88 \\
16.58 \\
0.0395 \\
85.1\end{array}$ & $\begin{array}{c}6.54 \\
0.62 \\
0.94 \\
2.98 \\
0.022 \\
27.64\end{array}$ \\
\hline Chaunax multilepis & $\begin{array}{l}O A \\
O H \\
O L \\
O P \\
O W \\
S L\end{array}$ & 16 & $\begin{array}{c}12.9 \\
3.59 \\
1.62 \\
13.3 \\
0.021 \\
68\end{array}$ & $\begin{array}{c}22.1 \\
4.53 \\
4.81 \\
17.7 \\
0.048 \\
109\end{array}$ & $\begin{array}{c}17.83 \\
4.07 \\
5.76 \\
15.86 \\
0.0325 \\
92\end{array}$ & $\begin{array}{c}2.64 \\
0.24 \\
0.5 \\
1.28 \\
0.007 \\
11.02\end{array}$ \\
\hline Halieutaea coccinea & $\begin{array}{l}O A \\
O H \\
O L \\
O P \\
O W \\
S L\end{array}$ & 16 & $\begin{array}{c}3.47 \\
1.75 \\
2.89 \\
11.1 \\
0.006 \\
49\end{array}$ & $\begin{array}{c}10.21 \\
3.13 \\
5.19 \\
22.1 \\
0.015 \\
110\end{array}$ & $\begin{array}{c}7.3 \\
2.51 \\
4.25 \\
15.13 \\
0,01 \\
75.12\end{array}$ & $\begin{array}{c}1.78 \\
0.36 \\
0.59 \\
3.28 \\
0.003 \\
17.46\end{array}$ \\
\hline Lophiodes lugubris & $\begin{array}{l}O A \\
O H \\
O L \\
O P \\
O W \\
S L\end{array}$ & 15 & $\begin{array}{c}6.31 \\
2.46 \\
3.69 \\
10.3 \\
0.006 \\
91\end{array}$ & $\begin{array}{c}15 \\
3.52 \\
6,3 \\
16.6 \\
0,03 \\
170\end{array}$ & $\begin{array}{c}9.98 \\
2.99 \\
4.73 \\
13.13 \\
0.134 \\
118.5\end{array}$ & $\begin{array}{c}3.18 \\
0.36 \\
0.93 \\
2.2 \\
0.007 \\
22.6\end{array}$ \\
\hline Malthopsis lutea & $\begin{array}{l}O A \\
O H \\
O L \\
O P \\
O W \\
S L\end{array}$ & 12 & $\begin{array}{c}6.33 \\
3.48 \\
2.19 \\
9.6 \\
0.006 \\
41\end{array}$ & $\begin{array}{c}9.69 \\
4.63 \\
2.91 \\
11.96 \\
0.021 \\
67\end{array}$ & $\begin{array}{c}8 \\
4.02 \\
2.59 \\
10.73 \\
0.016 \\
57.25\end{array}$ & $\begin{array}{c}1.18 \\
0,3 \\
0.22 \\
0.75 \\
0.004 \\
7.16\end{array}$ \\
\hline
\end{tabular}
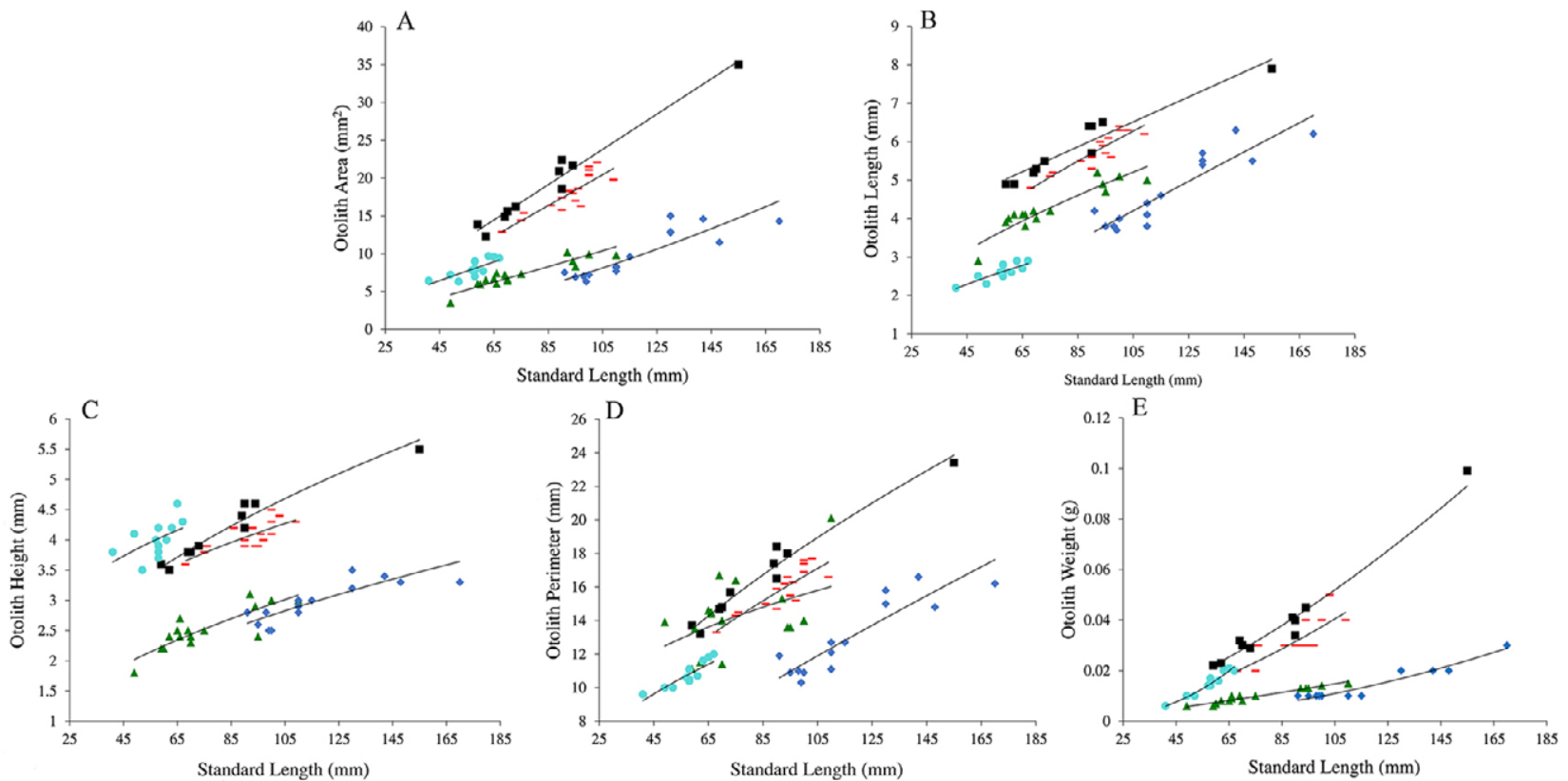

Appendix 2. - Relationship between fish size $(S L, \mathrm{~cm})$ and otolith morphometric variables (A, otolith area; B, otolith length; C, otolith height; $\mathrm{D}$, otolith perimeter; E, otolith weight) for the five most common deep-sea benthic anglerfishes from the Andaman and Nicobar Islands (eastern Indian Ocean). C. multilepis, red dash; C. apus, black square; L. lugubris, blue diamond; H. coccinea, green triangle; M. lutea, blue circle. 
Appendix 3. - Results of the ANCOVA for the relationship between fish size $(S L)$ and otolith measurements of the five most common deep-sea benthic anglerfishes from the Andaman and Nicobar Islands (eastern Indian Ocean). $O A$, otolith area; $O H$, otolith height; $O L$, otolith length; $O P$, otolith perimeter; $O W$, otolith weight; $S L$, standard length; df, degrees of freedom; Sum Sq, sum of squares; Mean Sq, mean sum of squares; $P r$, significance level. Statistically significant differences indicated in bold.

\begin{tabular}{llccccc}
\hline Variable & df & Sum Sq & Mean Sq & F value & $\operatorname{Pr}(>F)$ \\
\hline$O A$ & & & & & & \\
& $S L$ & 1 & 0.760 & 0.760 & 371.152 & $<\mathbf{0 . 0 0 1}$ \\
& Species & 4 & 1.873 & 0.470 & 229.436 & $<\mathbf{0 . 0 0 1}$ \\
& SL: Species & 4 & 0.018 & 0.004 & 2.158 & 0.085 \\
& Residuals & 59 & 0.121 & 0.002 & & \\
$O H$ & & & & & & \\
& SL & 1 & 0.011 & 0.101 & 15.474 & $\mathbf{< 0 . 0 0 1}$ \\
& Species & 4 & 0.657 & 0.164 & 238.848 & $<\mathbf{0 . 0 0 1}$ \\
& SL: Species & 4 & 0.002 & 0.001 & 0.879 & 0.482 \\
& Residuals & 59 & & & & \\
$O L$ & & & & & & \\
& SL & 1 & 0.660 & 0.660 & 1074.370 & $<\mathbf{0 . 0 0 1}$ \\
& Species & 4 & 0.531 & 0.133 & 216.269 & $<\mathbf{0 . 0 0 1}$ \\
& SL: Species & 4 & 0.012 & 0.003 & 4.764 & 0.002 \\
& Residuals & 59 & 0.036 & 0.001 & & \\
$O P$ & & & & & & \\
& SL & 1 & 0.157 & 0.157 & 127.371 & $<\mathbf{0 . 0 0 1}$ \\
& Species & 4 & 0.240 & 0.060 & 48.657 & $<\mathbf{0 . 0 0 1}$ \\
& SL: Species & 4 & 0.013 & 0.003 & 2.706 & 0,039 \\
& Residuals & 57 & 0.070 & 0.001 & & \\
$O W$ & & & & & & \\
& SL & 1 & 0.957 & 0.957 & 350.515 & $<\mathbf{0 . 0 0 1}$ \\
& Species & 4 & 3.746 & 0.936 & 343.147 & $<\mathbf{0 . 0 0 1}$ \\
& SL: Species & 4 & 0.074 & 0.019 & 6.787 & $<\mathbf{0 . 0 0 1}$ \\
& Residuals & 59 & 0.161 & 0.003 & & \\
\hline
\end{tabular}

Appendix 4. - Correlation between principal components and functional traits (see text for acronyms) of the five most common deep-sea benthic anglerfishes from the Andaman and Nicobar Islands (eastern Indian Ocean). In bold, higher absolute correlation values $(r>0.3)$

\begin{tabular}{lcccccc}
\hline Traits & PC 1 & PC 2 & PC 3 & PC 4 & PC 5 & PC 6 \\
\hline Osf & -0.030 & -0.068 & 0.153 & $\mathbf{0 . 7 3 9}$ & 0.253 & $\mathbf{0 . 3 0 6}$ \\
Osh & -0.034 & 0.019 & 0.012 & 0.120 & $\mathbf{0 . 6 5 3}$ & -0.101 \\
Ops & 0.050 & -0.084 & 0.168 & 0.499 & $\mathbf{- 0 . 5 4 8}$ & -0.066 \\
Edst & 0.075 & 0.037 & -0.051 & -0.149 & $\mathbf{- 0 . 3 0 2}$ & 0.041 \\
Eps & -0.018 & -0.022 & 0,039 & 0.233 & -0.166 & 0.061 \\
Bsh & -0.236 & -0.012 & -0.169 & 0.056 & -0.077 & 0.215 \\
CPt & -0.084 & 0.274 & 0.162 & 0.182 & 0.160 & $\mathbf{- 0 . 6 8 6}$ \\
$F S r$ & 0.013 & 0.021 & 0.137 & -0.139 & 0.212 & $\mathbf{0 . 5 7 0}$ \\
$F S b$ & $\mathbf{0 . 8 6 8}$ & 0.130 & $\mathbf{0 . 3 6 0}$ & -0.045 & 0.041 & 0.035 \\
ArPF & $\mathbf{0 . 3 5 0}$ & $\mathbf{0 . 3 0 9}$ & $\mathbf{- 0 . 8 3 4}$ & 0.236 & 0.028 & 0.026 \\
ArCF & -0.225 & $\mathbf{0 . 8 9 3}$ & 0.212 & -0.014 & -0.109 & 0.205 \\
\hline
\end{tabular}

Appendix 5. - Results of the inter-species classification using canonical variate analysis for fish body shape of the five most common deep-sea benthic anglerfishes from the Andaman and Nicobar Islands (eastern Indian Ocean). Predicted group membership in each group are in bold letters and percentage of classification is in parenthesis.

\begin{tabular}{|c|c|c|c|c|c|c|}
\hline Species & Chaunax apus & Chaunax multilepis & Halieutaea coccinea & Lophiodes lugubris & Malthopsis lutea & Total \\
\hline Chaunax apus & $10(100)$ & 0 & 0 & 0 & 0 & 10 \\
\hline Chaunax multilepis & 0 & $16(100)$ & 0 & 0 & 0 & 16 \\
\hline Halieutaea coccinea & 0 & 0 & $19(95)$ & 1 & 0 & 20 \\
\hline Lophiodes lugubris & 0 & 0 & 1 & $\mathbf{1 7}(89.5)$ & 3 & 21 \\
\hline Malthopsis lutea & 0 & 0 & 0 & 1 & $14(82.3)$ & 15 \\
\hline
\end{tabular}

